\title{
RELAÇÕES ÉTNICO-RACIAIS E EDUCAÇÃO: O ESTADO DO CONHECIMENTO A PARTIR DE QUATRO PERIÓDICOS DAS REGIÕES NORTE-NORDESTE
}

\section{ETHNIC-RACIAL RELATIONSHIPS AND EDUCATION: THE STATE OF KNOWLEDGE FROM FOUR PERIODS OF THE NORTH-NORTHEAST REGIONS}

\section{RELACIONES ETNICO-RACIALES Y EDUCACIÓN: EL ESTADO DEL CONOCIMIENTO DE CUATRO PERÍODOS DE LAS REGIONES NOROESTE}

Arlete Ramos dos Santos ${ }^{1}$

Edmacy Quirina de Souza ${ }^{2}$ Letícia Santos Azevedo ${ }^{3}$

Resumo: Este artigo objetiva mapear e analisar as produções acadêmicas nos periódicos Revista Educação \& Formação, Revista Exitus, Revista Práxis Educacional e Revista Tempos e Espaços em Educação das regiões Norte e Nordeste, destacando o dialogo étnico-racial em interface com a educação, dentro do recorte temporal de 2010-2020. O caráter metodológico se encontra embasado no Estado da Arte. Foram levantados setenta e quatro (74) artigos das quatro (04) revistas no período de janeiro de 2010 a junho de 2020. Os resultados deste levantamento apontam ínfimas produções que tratam das relações étnico-raciais nos primeiros anos do recorte temporal delimitado, havendo exitosa ascendência a partir do ano de 2019, obtendo, assim, um total de 33 publicações. As revistas Práxis Educacional e Exitus, possuem maior quantitativo de artigos, sendo 31 e 29 artigos, respectivamente.

Palavras-Chave: Racismo. Educação. Produção Acadêmica. Estado da Arte.

Abstract: This article aims to map and analyze academic productions in the journals Revista Educação \& Formação, Revista Exitus, Revista Práxis Educacional and Revista Tempos e Espaços em

\footnotetext{
${ }^{1}$ Universidade Estadual do Sudoeste da Bahia. Vitória da Conquista-Bahia, Brasil.

${ }^{2}$ Universidade Estadual do Sudoeste da Bahia. Itapetinga-Bahia, Brasil

${ }^{3}$ Universidade Estadual do Sudoeste da Bahia. Itapetinga-Bahia, Brasil
} 
Educação in the North and Northeast regions, highlighting the ethnic-racial dialogue in interface with education, within the outline 2010-2020. The methodological character is based on the State of Art. Seventy-four (74) articles were collected from the four (04) journals in the period from January 2010 to June 2020. The results of this survey point to very small productions that deal with ethnic-racial relations in the first years of the delimited time frame, with successful ascendancy from the year 2019, thus obtaining a total of 33 publications. The magazines Práxis Educacional and Exitus have the highest number of articles, with an amount of 31 and 29 articles, respectively.

Keywords: Racism. Education. Academic Production. State of art.

Resumen: Este artículo tiene como objetivo mapear y analizar las producciones académicas en las revistas Revista Educação \& Formação, Revista Exitus, Revista Práxis Educacional y Revista Tempos e Espaços em Educação en las regiones Norte y Nordeste, destacando el diálogo étnico-racial en la interfaz con la educación, dentro de la marcación temporal 2010-2020. El carácter metodológico se basa en el estado del arte. Se recogieron setenta y cuatro (74) artículos de las cuatro (04) revistas en el período de enero de 2010 a junio de 2020. Los resultados de esta encuesta apuntan a producciones muy pequeñas que tratan las relaciones étnico-raciales en los primeros años del marco de tiempo delimitado, con ascendencia exitosa desde el año 2019, obteniendo así un total de 33 publicaciones. Las revistas Práxis Educacional y Exitus tienen el mayor número de artículos, 31 y 29 artículos, respectivamente.

Palabras clave: Racismo. Educación. Producción Académica. Estado del arte.

\section{INTRODUÇÃO}

Na sociedade brasileira o racismo se desenvolve estabelecendo uma separação que é feita a partir da cor/raça. Comportamentos de aversão e, por vezes, ódio em relação às pessoas que possuem um pertencimento racial observável por meio de traços, tais como: cor da pele, tipo de cabelo etc., têm permitido ao grupo étnico branco ocupar posição de superioridade na hierarquia social, enquanto os negros são postos em condição subalterna de inferioridade, advindo, daí o racismo, o qual tem transformado a diversidade em desigualdade.

Esta diferenciação entre pessoas brancas e negras manifestada no interior de muitas instituições como o Estado, empresas, escola, TV etc., demostra um racismo institucional e, historicamente, estrutural. Nesse sentido, é preciso entender que o racismo é real e precisa ser combatido, discutido, problematizado cotidianamente, descontruindo, assim, o mito da democracia racial.

Por democracia racial entende-se como a crença de que o Brasil era uma sociedade sem linha de cor, sem preconceito e discriminações raciais, e que os diferentes grupos étnicos viviam harmoniosamente na sociedade. Construiu-se discursos de que as pessoas negras haviam sido 
inteiramente integradas à nação brasileira (GUIMARÃES, 2001). Tal ideário no cenário brasileiro alinhase ao pseudodiscurso antirracista, ademais, o caráter falacioso desta democracia racial é referenciado em muitas das produções analisadas neste artigo, apresentam justamente esta democracia como um mito, pois ela nunca existiu de fato no Brasil.

Assim, a sistematização do estudo busca apresentar a importância desta temática nas pesquisas acadêmicas publicadas, nas quais observamos que destacam as seguintes conquistas: advento de dispositivos legais de enfrentamento a discriminação, aumento da presença de negros nas universidades, reconhecimento e valorização da cultura afro-brasileira, o fomento de estratégias que auxiliam a construção de uma identidade positiva de crianças e adolescentes negros. Sendo assim, este artigo se propõe mapear e analisar as produções acadêmicas nas revistas Revista Educação \& Formação, Revista Exitus, Revista Práxis Educacional e Revista Tempos e Espaços em Educação das regiões Norte e Nordeste, destacando o dialogo étnico-racial em interface com a educação, dentro do recorte temporal de 2010-2020.

O estudo utilizou como metodologia o Estado da Arte que visa sistematizar e discutir a produção de conhecimento em determinada área, destacando os aspectos relevantes da pesquisa, épocas, lugares, como também as lacunas que, porventura, venham apresentar determinada pesquisa. Para Romanowski e Ens (2006, p. 39), o Estado da Arte aponta "restrições sobre o campo em que se move a pesquisa, as suas lacunas de disseminação", busca "identificar experiências inovadoras investigadas que apontem alternativas de solução para os problemas da prática e reconhecer as contribuições da pesquisa na constituição de propostas na área focalizada".

Neste caso, o que está sendo investigado, são produções publicadas nas quatro revistas pesquisadas. Para construir os dados fizemos um recorte temporal de janeiro de 2010 a junho de 2020. As informações e dados contidos nesta pesquisa foram retirados dos arquivos e edições divulgados nos sites oficiais das próprias revistas. Importante destacar que, embora o recorte tenha sido a partir de 2010, a Revista Educação e Formação inicia sua publicação no ano de 2016; e a Revista Exitus, em 2011.

Para classificação e catalogação dos trabalhos foram considerados o Título do artigo, objetivo da pesquisa e palavras-chave, possibilitando, assim, relacionar o artigo às temáticas educação e relações étnico-raciais. Este artigo está estruturado da seguinte forma: Introdução, na qual destacamos, objetivo e a metodologia utilizada com foco na pesquisa a partir do Estado da Arte; no segundo momento, delineamos o Estado da Arte propriamente dito, no qual levantamos o quantitativo de artigos publicados em cada periódico pesquisado, bem como os aspectos 
observados em tais achados. Por fim, são tecidas as considerações evidenciadas pelas autoras após conclusão do estudo.

\section{ESTADO DA ARTE DAS RELAÇÕES ÉTNICO RACIAIS A PARTIR DO MARCADOR RACIAL NAS REVISTAS NO NORTE-NORDESTE}

As quatro (04) revistas supracitadas constituem-se em importantes periódicos das regiões Norte e Nordeste envolvem os programas de Pós-Graduação em Educação da Universidade Federal do Oeste do Pará - UFOPA (Revista Exitus), da Universidade Estadual do Ceará - UECE (Revista Educação \& Formação), da Universidade Estadual do Sudoeste da Bahia - UESB (Revista Práxis Educacional ) e da Universidade Federal de Sergipe - UFS (Revista Tempos e Espaços em Educação). Todos esses periódicos, cuja periodicidade está destacada no quadro 1, buscam incentivar o debate, construir o conhecimento e divulgar produções acadêmico-cientificas na área da educação, bem como em subáreas como Formação de Professor, Políticas e Gestão Educacional, Práticas Pedagógicas, Conhecimento e Cultura, Educação e Diversidade, História da Educação, entre outras temáticas relacionadas ao campo da educação.

Quadro 1 - Dados das revistas pesquisadas.

\begin{tabular}{|l|l|c|c|}
\hline \multicolumn{1}{|c|}{ REVISTAS } & PRIMEIRO VOLUME & $\begin{array}{c}\text { VOLUMES } \\
\mathbf{2 0 1 0 - 2 0 2 0}\end{array}$ & $\begin{array}{c}\text { ANOS DAS } \\
\text { PUBLICAÇOEES SOBRE } \\
\text { AS RELAÇOES } \\
\text { ÉTNICO-RACIAIS. }\end{array}$ \\
\hline Revista Exitus & Julho e dezembro de 2011. & 23 volumes & 2012 e 2020 \\
\hline $\begin{array}{l}\text { Revista Educação \& } \\
\text { Formação }\end{array}$ & Janeiro e abril de 2016. & 15 volumes & 2017 a 2020 \\
\hline Revista Práxis Educacional & Agosto de 2005. & 31 volumes & 2013 a 2020 \\
\hline $\begin{array}{l}\text { Revista Tempos e Espaços } \\
\text { em Educação }\end{array}$ & Julho e dezembro 2008. & 30 volumes & 2019 \\
\hline
\end{tabular}

Apenas a Revista Educação \& Formação possui uma periodicidade quadrimestral, ou seja, publica três volumes por ano, enquanto que as demais publicam trimestralmente. A revista mais antiga, com 15 anos de existência é a Práxis Educacional, criada em 2005; e a mais nova, a Educação \& Formação, foi implementada em 2016, ou seja, 06 anos após o nosso recorte temporal. Talvez isso justifique o quantitativo menor de publicação sobre a temática. As publicações dos quatro periódicos acontecem entre os anos de 2012 e 2020. 
Para a sistematização e análise dos artigos que tratam da temática relações étnico-raciais e educação, consideramos os aspectos: título do artigo, objetivo da pesquisa e palavras-chave. A partir desses aspectos foram levantados temas como currículo e relações étnico-raciais, formação docente, racismo, as leis 10.639/2003 e 11.645/2008, ações afirmativas, negro/a, diversidade, diferença, africanidades, afrocentrismo, livro didático, identidade negra, educação quilombola etc.

Na catalogação por periódico, observamos que a Revista Práxis Educacional possui um quantitativo maior de publicação sobre as relações étnico-raciais e educação no período de 10 anos. O segundo periódico com maior quantidade de publicação é a Revista Exitus, que, mesmo tendo sido criada um ano depois do nosso recorte temporal, possui 29 publicações nesses nove anos de existência. A Revista Tempos e Espaços em Educação, está em terceiro lugar com 11 artigos. Esta, mesmo tendo uma trajetória de 12 anos, não traz um volume significativo da temática pesquisada. A Revista Educação e Formação publicou três artigos no período de 04 anos. Referendando tal levantamento, apresentamos o seguinte quadro:

Quadro 2 - Publicações por ano sobre as relações étnico-raciais nas revistas pesquisadas.

\begin{tabular}{|c|c|c|c|c|c|}
\hline ANO & $\begin{array}{c}\text { REVISTA } \\
\text { EDUCAÇÃO } \\
\& \\
\text { FORMAÇÃO }\end{array}$ & $\begin{array}{c}\text { REVISTA } \\
\text { EXITUS }\end{array}$ & $\begin{array}{c}\text { REVISTA } \\
\text { PRÁXIS } \\
\text { EDUCACIONAL }\end{array}$ & $\begin{array}{c}\text { REVISTA } \\
\text { TEMPOS E } \\
\text { ESPAÇOS EM } \\
\text { EDUCAÇÃO }\end{array}$ & $\begin{array}{c}\text { PUBLICAÇÃO } \\
\text { NAS QUATRO } \\
\text { REVISTAS POR } \\
\text { ANO }\end{array}$ \\
\hline 2010 & & -- & 00 & 00 & 00 \\
\hline 2011 & & Ano de Criação & 00 & 00 & 00 \\
\hline 2012 & & 02 & 00 & 00 & 02 \\
\hline 2013 & & 00 & 01 & 00 & 01 \\
\hline 2014 & & 01 & 00 & 04 & 05 \\
\hline 2015 & & 00 & 08 & 01 & 09 \\
\hline 2016 & Ano de Criação & 00 & 03 & 01 & 04 \\
\hline 2017 & 01 & 01 & 02 & 00 & 04 \\
\hline 2018 & 01 & 01 & 01 & 01 & 04 \\
\hline 2019 & 00 & 21 & 08 & 04 & 33 \\
\hline 2020 & 01 & 03 & 08 & 00 & 12 \\
\hline TOTAL & $\mathbf{0 3}$ & 29 & 31 & 11 & 74 \\
\hline
\end{tabular}

De acordo com o quadro 2, é possível perceber o quantitativo de artigos publicados em cada revista e o seu montante no ano. Nota-se que 2019 foi um ano expressivo na publicação de artigos que discutem as relações étnico-raciais, totalizando trinta e três (33) artigos. Importante destacar que neste período houve dois dossiês publicados: Um pela revista Exitus e outro pela Práxis Educacional. A revista Exitus possui vinte e um (21) artigos sobre a temática no ano de 2019, de modo que este periódico, além do dossiê temático, apresenta no volume 09, número 05, oito (08) 
artigos. Observamos que no ano em curso (janeiro a junho de 2020), já temos um quadro de doze (12) artigos divulgados por três, das quatro revistas pesquisadas. Entre os anos de 2012 e 2020 os quatro periódicos publicaram setenta e quatro (74) artigos sobre a temática investigada.

Embora seja um expressivo volume de produções, e a inclinação de pesquisadores frente a temática racial galgue espaço de grande relevância contra o enfretamento de preconceitos e discriminações nos últimos anos, há de pontuar a necessidade de fomento das mesmas, bem como sua real carência, como apontam os dados da Revista Educação \& Formação. Tal estímulo tem como missão elevar os índices de debates sobre racismo; combater o ódio e a política de violência histórica e vigente contra negros e negras; coibir comportamentos racistas que eclodem constantemente por vilas e vielas desse país tão diverso.

A Revista Educação e Formação, nesses quatro anos de existência, traz três (03) artigos que versam sobre as relações étnico-raciais, diferença racial e africanidades. Ver o quadro 3:

Quadro 3 - Artigos da Revista Educação e Formação.

\begin{tabular}{|c|l|l|c|}
\hline $\mathbf{N}^{\mathbf{0}}$ & \multicolumn{1}{|c|}{ AUTOR } & \multicolumn{1}{c|}{ TÍTULO DO ARTIGO } & ANO \\
\hline 01 & $\begin{array}{l}\text { Wolney Nascimento Santos } \\
\text { Hamilcar Silveira Dantas Junior } \\
\text { Fabio Zoboli }\end{array}$ & $\begin{array}{l}\text { Cinema, educação e africanidades: a memória no documentário } \\
\text { Caixa d'água: qui-lombo é esse? }\end{array}$ & 2020 \\
02 & $\begin{array}{l}\text { Lívia Maria Serafim Duarte Oliveira } \\
\text { Patrícia Cristina de Aragão. }\end{array}$ & $\begin{array}{l}\text { As questões étnico-raciais nas histórias em quadrinhos e as } \\
\text { práticas educativas na formação inicial docente. }\end{array}$ & 2018 \\
\hline 03 & Janote Pires Marques & $\begin{array}{l}\text { Além da história, a tradição oral: Considerações sobre o ensino de } \\
\text { história da África na educação básica. }\end{array}$ & 2017 \\
\hline
\end{tabular}

O artigo Cinema, educação e africanidades: a memória no documentário Caixa d'água: quilombo é esse? analisa o documentário objetivando problematizar e flexionar a história e a memória dos povos africanos e afrodescendentes na formação do povo brasileiro, ressignificando a existência negra. Para Santos, Dantas Junior e Zoboli, (2020, p. 03), "por meio das imagens, sons e sensações" é preciso construir "histórias outras para além dos discursos oficiais que hegemonicamente determinaram parte da cena cinematográfica brasileira", pois, as relações raciais nas instituições de ensino ainda são "marcadas por grandes fossos de desigualdades, apesar do reconhecimento legal e político por parte do Estado", daí a importância de "discutir o corpo negro e os signos" que emergem no ambiente escolar.

O texto As questões étnico-raciais nas histórias em quadrinhos e as práticas educativas na formação inicial docente, discute as questões étnico-raciais, no contexto da formação inicial docente, no ensino superior privado, a partir da utilização das histórias em quadrinhos. As autoras consideram as experiências e os saberes desenvolvidos pelos docentes em seu cotidiano, uma forma 
de incorporar as iniciativas de ruptura contra as desigualdades sociais, culturais e raciais (OLIVEIRA; ARAGÃO, 2018).

O artigo Além da história, a tradição oral: Considerações sobre o ensino de história da África na educação básica propõe uma interlocução entre a tradição oral africana e a História da África. O autor destaca a importância da tradição oral para entender a História da África e dos africanos e, nesse sentido, se construir um ensino voltado à temática na educação básica, ajudando a escrever e reescrever uma História da África de forma positiva (MARQUES, 2017).

A Revista Práxis Educacional apresenta uma quantidade expressiva de artigos no objeto relações étnico-raciais, com três (03) Dossiês Temáticos. O primeiro Dossiê, intitulado Currículo e Diversidade 4 , com 07 artigos, traz discussões significativas sobre educação, raça, etnia, gênero, educação indígena e quilombola. Dentro desse universo há inúmeras possiblidades de se pensar o currículo a partir da diversidade que se manifesta no ambiente escolar, conforme pode se verificar nos temas descritos no Quadro 4. Ainda neste mesmo número da revista há um artigo de fluxo contínuo que discute os Avanços e desafios no processo de implementação da Lei 10.639/03 na Rede Municipal de Ensino de Jequié-Ba: os discursos do campo recontextualizador oficial. O presente artigo versa sobre o discurso pedagógico das gestoras acerca dos desafios e avanços no processo de discussão e implementação da Lei no 10.639/03 e reconhece a importância dos estudos sobre as relações raciais em consonância com a formação continuada dos professores (SOUZA; SANTOS; EUGÊNIO, 2015).

Quadro 4 - Primeiro Dossiê da Revista Práxis Educacional.

\begin{tabular}{|c|l|l|c|}
\hline $\mathbf{N}^{\mathbf{0}}$ & \multicolumn{1}{|c|}{ AUTORES/AS } & \multicolumn{1}{|c|}{ TÍTULO DO ARTIGO } & ANO \\
\hline 01 & $\begin{array}{l}\text { Ivanilda Amado Cardoso } \\
\text { Rosane Michelli de Castro }\end{array}$ & $\begin{array}{l}\text { A ausência/presença das relações étnico-raciais nos currículos dos } \\
\text { cursos de pedagogia: o caso da Unesp/Marília }\end{array}$ & 2015 \\
\hline 02 & Amurabi Pereira de Oliveira & $\begin{array}{l}\text { Gênero, sexualidade e diversidade no currículo escolar: a } \\
\text { experiência do papo sério em Santa Catarina }\end{array}$ & 2015 \\
\hline 03 & Luiz Fernandes de Oliveira & $\begin{array}{l}\text { Concepções docentes sobre as relações étnico-raciais em educação } \\
\text { e a Lei 10.639/03 }\end{array}$ & 2015 \\
\hline 04 & Marco Antônio Oliva Gomes & $\begin{array}{l}\text { Diversidade e diferença no aprender ensinar: ou sobre fragmentos } \\
\text { de infância, bons encontros e cuidado de si }\end{array}$ & 2015 \\
\hline 05 & Thais Alves Marinho & Educação Quilombola: entre o mito e o fato & 2015 \\
\hline 06 & $\begin{array}{l}\text { Paulo de Tássio Borges da } \\
\text { Silva } \\
\text { Maria Inêz Oliveira Araújo }\end{array}$ & $\begin{array}{l}\text { Diálogos sobre interculturalidade, conhecimento científico e } \\
\text { conhecimentos tradicionais na educação escolar indígena }\end{array}$ & 2015 \\
\hline
\end{tabular}

\footnotetext{
${ }^{4}$ Em relação as discussões sobre currículo ler os trabalhos de Rudd e Goodson (2016), Uljens (2016), Pacheco e Sousa (2016), Morgado (2016), Moreira e Silva Junior (2016), Kovacs e Tinoca (2017), Fino (2016), Sousa (2016), Pedro (2017), Dias e Menezes (2017), Menezes, Dias e Santos (2020), Cruz (2014), Dias (2014), Zotti (2006) e Onofre (2008).
} 
Neste Dossiê queremos destacar alguns artigos que possuem uma relação mais direta com a educação e as relações étnico-raciais a partir do marcador racial negro. $O$ artigo $A$ ausência/presença das relações étnico-raciais nos currículos dos cursos de pedagogia: o caso da Unesp/Marília, objetiva analisar os planos de ensino (ementas, programas) e os projetos políticos pedagógicos do curso de Pedagogia da Faculdade de Filosofia e Ciências (FFC) - Unesp/Marília, com vistas à educação das relações étnico-raciais. Neste artigo, as autoras buscam responder à pergunta se as relações étnico/raciais foram privilegiadas na formação de professores/as no curso de Pedagogia da Unesp de Marília, e como o curso ao longo de sua trajetória tem abordado a temática racial. Assim, as autoras chegam a conclusão de que a "[...] ausência do debate sobre relações étnico-raciais e educação nos currículos dos cursos de formação de professores/as é atualmente um dos entraves para o processo de implantação e implementação da Lei n. 10.639/03 nas escolas" (CARDOSO; CASTRO, 2015, p. 111).

A produção Concepções docentes sobre as relações étnico-raciais em educação e a Lei 10.639/03, problematiza os conflitos étnico-raciais e a tensão entre igualdade e diferença nas subjetividades e nas concepções docentes diante da aplicação das Diretrizes Curriculares Nacionais para a Educação das Relações Étnico-raciais em Educação e para o Ensino de História e Cultura AfroBrasileira e Africana no currículo do Ensino Básico. A partir de uma "leitura intercultural dos processos educativos", o autor destaca que "a educação das relações étnico-raciais são muito mais complexas e tensas do que se possa imaginar", pois exige "dos docentes a aplicação das novas diretrizes que incluem nos currículos, histórias da África e das relações étnico-raciais em educação” e, para isso, "significa mobilizar subjetividades, desconstruir noções e concepções apreendidas durante os anos de formação inicial e enfrentar preconceitos raciais muito além dos muros escolares" (OLIVEIRA, 2015, p. 45).

Outro artigo que merece destaque aborda o Trabalho docente e construção de identidades: condições, possibilidades e limites do trabalho sobre relações étnico/raciais no espaço escolar. Neste estudo as autoras refletem sobre a percepção do pertencimento étnico-racial de professoras negras e sua intrínseca relação com o processo de construção da identidade das mesmas e destacam que a negação e a invisibilidade da população negra se constituem práticas recorrentes em nossa sociedade. Atentam para o reconhecimento dos dispositivos legais, bem como da Lei $\mathrm{n}$ ㅇ 
10.639/2003 que institui a obrigatoriedade do ensino da História e da Cultura Afro-Brasileira e Africana nos currículos escolares (SILVA; SANTIAGO, 2015).

Já o artigo Educação Quilombola: entre o mito e o fato, busca avaliar como a educação para a diversidade foi inserida na comunidade remanescente de Quilombo Kalunga, do nordeste de Goiás, objetivando entender as diretrizes seguidas por esse modelo de educação, bem como os dilemas inaugurados por essa mudança no modelo de educação formal (MARINHO, 2015).

Seguindo a linha de análise, frisamos ao leitor que os demais artigos referenciados foram eleitos por trazerem uma discussão mais direta com o marcador racial negro e o campo da escola, objeto proposto para levantamento dos dados. Em 2019, esta mesma revista traz o Dossiê: Saberes docentes de intelectuais negras: mediações outras frente ao ethos acadêmico, com 07 artigos discriminados no Quadro 5.

Quadro 5 - Segundo Dossiê da Revista Práxis Educacional.

\begin{tabular}{|c|l|l|c|}
\hline $\mathbf{N}^{\mathbf{0}}$ & \multicolumn{1}{|c|}{ AUTORES/AS } & \multicolumn{1}{c|}{ TÍTULO DO ARTIGO } & ANO \\
\hline 01 & $\begin{array}{l}\text { Núbia Regina Moreira } \\
\text { Nadila Jardim Evangelista } \\
\text { João Paulo Lopes dos Santos }\end{array}$ & $\begin{array}{l}\text { A experiência feminina negra e suas interrogaçòes à política e } \\
\text { prática curriculares }\end{array}$ & 2019 \\
\hline 02 & $\begin{array}{l}\text { Maria Simone Euclides } \\
\text { Joselina da Silva }\end{array}$ & $\begin{array}{l}\text { Dialogando autoetnografias negras: intersecções de vozes, saberes } \\
\text { e práticas docentes }\end{array}$ & 2019 \\
\hline 03 & Anny Ocoró Loango & $\begin{array}{l}\text { Emancipación y descolonización: tensiones, luchas y aprendizajes } \\
\text { de los investigadores/as negros/as en la educación superior }\end{array}$ & 2019 \\
\hline 04 & $\begin{array}{l}\text { Sônia Beatriz dos Santos } \\
\text { Ilaina Damasceno }\end{array}$ & $\begin{array}{l}\text { Experiências de professoras/ intelectuais negras na universidade: } \\
\text { entre o direito à diferença e a competência pedagógica }\end{array}$ & 2019 \\
\hline 05 & $\begin{array}{l}\text { Iris Verena Oliveira } \\
\text { Narrativa de práticas docentes como intelectual negra: invenções e } \\
\text { rasuras }\end{array}$ & 2019 \\
\hline 06 & $\begin{array}{l}\text { Claudia Miranda } \\
\text { Ana Beatriz da Silva } \\
\text { Carla Silva } \\
\text { Elaine Barbosa }\end{array}$ & $\begin{array}{l}\text { Presença de mulheres negras na pesquisa em educação: conversas } \\
\text { sobre o estágio docente }\end{array}$ & 2019 \\
\hline 07 & $\begin{array}{l}\text { Rosa Campoalegre Septien } \\
\text { Una escuela tan negra como nosotras: desafíos ante el racismo y el } \\
\text { patriarcado }\end{array}$ & 2019 \\
\hline
\end{tabular}

Os artigos que compõem o presente dossiê destacam pesquisas e investigações com foco na experiência de mulheres negras como docentes e pesquisadoras. Cada artigo apresenta de forma ímpar o olhar sobre a mulher negra como intelectual no contexto universitário, focando na vida e experiência dessas mulheres, na sua trajetória escolar, como também na profissional, destacando o fazer científico e o exercício da docência no ensino superior, a partir de uma abordagem que privilegia a relação entre teoria e experiência como possibilidade de entrelaçar o trabalho intelectual com comunidades de pertencimento. Essas pesquisas produzem, ao mesmo tempo, narrativas a partir do lugar de fala da intelectual negra, apontando a diferença e a diversidade como potências dos fazeres e saberes promovidos pela mulher e negra (MOREIRA; 
EVANGELISTA; SANTOS, 2019; EUCLIDES; SILVA, 2019; SANTOS; DAMASCENO, 2019; OLIVEIRA, 2019; MIRANDA et all, 2019).

Este dossiê elege dois textos internacionais com importantes discussões sobre a temática. $\mathrm{O}$ primeiro, Emancipación y descolonización: tensiones, luchas y aprendizajes de los investigadores/as negros/as en la educación superior se constitui em um artigo latino americano que propõe um debate sobre pesquisadores/as negros/as no ensino superior, demostrando como a renda e a presença da pessoa negra "interpelam a desigualdade de oportunidades e as fortes barreiras raciais existentes nesses espaços acadêmicos". Aborda ainda "como as epistemologias hegemônicas apoiam o racismo institucional e epistêmico" (LOANGO, 2019, p. 54). O segundo, Una escuela tan negra como nosotras: desafíos ante el racismo y el patriarcado, cujo objetivo foi recuperar e narrar essa experiência, a partir da voz de uma mulher negra. Nesta pesquisa a autora aborda que Cuba vive um complexo contexto de mudanças no modelo econômico e social, que impacta o problema racial no país, e assegura que "a invisibilidade do pensamento negro de todos os tempos continua sendo uma questão a ser resolvida na luta contra o racismo", desta forma, 'a recuperação das histórias dos negros" se constitui em uma "premissa de converter suas narrativas 'subalternas' e transformá-las em insurgentes, geradoras de processos de descolonização" (SEPTIEN, 2019, p. 19).

Ainda neste número (v. 15, n. 32), a revista traz um artigo no fluxo contínuo, com o título: Quais as implicações para o fortalecimento da identidade negra no contexto da educação superior? no qual busca discutir as implicações que o acadêmico negro encontra no fortalecimento de sua identidade de forma positiva ou não. Destaca a democratização do ensino superior, o papel das ações afirmativas e a mudança no cenário das universidades públicas do país e o fortalecimento da identidade negra neste espaço hegemonicamente branco, que evidencia a monocultura e uma pedagogia eurocêntrica (MARQUES; RIBEIRO, 2019).

Em 2020, a revista apresenta seu terceiro dossiê denominado Formação docente, práticas pedagógicas e relações raciais e de gênero, composto por 08 artigos. Este dossiê aborda as categorias raça, gênero e sexualidade, bem como a intersecção das mesmas. Destacaremos apenas artigos que tratam do marcador racial negro. 
Quadro 6 - Terceiro Dossiê da Revista Práxis Educacional.

\begin{tabular}{|c|l|l|c|}
\hline $\mathbf{N}^{\mathbf{0}}$ & \multicolumn{1}{|c|}{ AUTORES/AS } & \multicolumn{1}{|c|}{ TÍTULO DO ARTIGO } & ANO \\
\hline 01 & $\begin{array}{l}\text { Silvani dos Santos Valentim } \\
\text { Jane Moreira }\end{array}$ & $\begin{array}{l}\text { Africanidades e tribalismo cultural: experiências de professores (as) } \\
\text { da cidade africana de Obuasi, Ghana }\end{array}$ & 2020 \\
\hline 02 & $\begin{array}{l}\text { Erisvaldo Pereira Santos } \\
\text { Catarina Dallapicula }\end{array}$ & $\begin{array}{l}\text { Travestilidades e transexualidades no candomblé e na educação: um } \\
\text { ensaio a partir de experiências }\end{array}$ & 2020 \\
\hline 03 & $\begin{array}{l}\text { Wilma de Nazaré Baía Coelho } \\
\text { Nicelma Josenila Costa de Brito }\end{array}$ & $\begin{array}{l}\text { Dez anos da lei n. 10.639/2003 e a formação de professores e } \\
\text { relações raciais em artigos (2003/2013): um tema em discussão }\end{array}$ & 2020 \\
\hline 04 & $\begin{array}{l}\text { Paulo Henrique Maia Melgaço } \\
\text { José Eustáquio de Brito } \\
\text { Santuza Amorim da Silva }\end{array}$ & $\begin{array}{l}\text { Educação das relações étnico-raciais: reflexões sobre uma formação } \\
\text { continuada na perspectiva de docentes }\end{array}$ & 2020 \\
\hline 05 & $\begin{array}{l}\text { Delton Aparecido Felipe } \\
\text { Samilo Takara }\end{array}$ & $\begin{array}{l}\text { Narrativas midiáticas sobre a sexualidade: educação, diferenças e } \\
\text { problemáticas à formação docente }\end{array}$ & 2020 \\
\hline 06 & $\begin{array}{l}\text { Kátia Evangelista Regis } \\
\text { Cidinalva Silva Câmara Neris } \\
\text { Sávio José Dias Rodrigues }\end{array}$ & $\begin{array}{l}\text { O global e o local na construção de uma educação emancipatória } \\
\text { para o ensino da história e cultura africana e afro-brasileira }\end{array}$ & 2020 \\
\hline 07 & $\begin{array}{l}\text { Lucimar Rosa Dias } \\
\text { Clarice Martins de Souza } \\
\text { Batista }\end{array}$ & $\begin{array}{l}\text { O movimento escola sem (?) Partido, práticas pedagógicas e a } \\
\text { educação das relações étnico-raciais }\end{array}$ & 2020 \\
\hline 08 & $\begin{array}{l}\text { Eugenia Portela Siqueira } \\
\text { Marques } \\
\text { Wilker Solidade da Silva }\end{array}$ & $\begin{array}{l}\text { Os desafios epistemológicos e práticos para o enfrentamento do } \\
\text { racismo no contexto escolar }\end{array}$ & 2020 \\
\hline
\end{tabular}

O artigo Africanidades e tribalismo cultural: experiências de professores (as) da cidade africana de Obuasi, Ghana, objetiva "apresentar as especificidades das experiências dos (as) professores (as), por meio de uma abordagem informativa, analítica e reflexiva das relações tribais culturais no espaço escolar, da valorização identitária dos povos de Ghana" (VALENTIM; MOREIRA, 2020, p. 115). Segundo as autoras, a problematização sobre "africanidades e as heranças afrodescendentes ainda são temas que carecem de aprofundamento na sociedade brasileira e na educação em suas diferentes modalidades, inclusive na educação básica" (idem, p. 116).

O artigo Dez anos da Lei n. 10.639/2003 e a formação de professores e relações raciais em artigos (2003/2013): um tema em discussão, se constitui em uma pesquisa que analisa o percurso da literatura especializada sobre a temática de formação de professores e relações raciais a partir de publicações em revistas com qualificações atribuídas entre A1 a B5. Percebe-se que este estudo se partir desenha aos moldes do Estado da Arte (COELHO; BRITO, 2020).

Os demais artigos deste dossiê discutem sobre a educação das relações raciais e formação docente, o ensino da história e cultura africana e afro-brasileira e a prática pedagógica, a escola sem partido e as relações étnico-raciais, bem como o enfrentamento do racismo no contexto escolar. Esses artigos permitem pensar e repensar a realidade educativa buscando ressignificar práticas que construam uma educação e, consequentemente, uma sociedade antirracista. 
Além desses três dossiês, a revista apresenta artigos relacionadas a temática nos anos de 2013, 2016, 2017 e 2018 que discorrem sobre as relações étnico-raciais, resistências, formação continuada para as relações raciais, currículo e diversidade, saberes quilombolas, religiosidades, cultura, descolonização curricular, diversidade étnico-racial e pesquisadoras negras.

Quadro 7 - Demais artigos publicados pela Revista Práxis Educacional entre 2013 a 2018.

\begin{tabular}{|c|l|l|c|}
\hline $\mathbf{N}^{\mathbf{0}}$ & \multicolumn{1}{|c|}{ AUTORES/AS } & \multicolumn{1}{|c|}{ TÍTULO DO ARTIGO } & ANO \\
\hline 01 & Claudia Miranda & $\begin{array}{l}\text { Pesquisadoras negras na docência do ensino superior: uma } \\
\text { análise a partir da perspectiva (auto)biográfica }\end{array}$ & 2018 \\
\hline 02 & $\begin{array}{l}\text { Marta Maria de Araújo } \\
\text { Raíra Mércia da Cunha } \\
\text { Paulo Basílio de Alcântara }\end{array}$ & $\begin{array}{l}\text { Educação escolar primária de mulheres e homens de cor negra } \\
\text { (rio grande do norte, 1931-1948) }\end{array}$ & 2017 \\
\hline 03 & Zilmar Santos Cardoso & $\begin{array}{l}\text { As políticas de ações afirmativas para a população negra: a lei } \\
10639 / 03 \text { e seus dispositivos legais }\end{array}$ & 2017 \\
\hline 04 & $\begin{array}{l}\text { Jeanes Martins Larchert } \\
\text { Maria Waldenez de Oliveira }\end{array}$ & $\begin{array}{l}\text { As (não) relações curriculares entre a epistemologia } \\
\text { quilombola e a educação escolar }\end{array}$ & 2016 \\
\hline 05 & $\begin{array}{l}\text { Maicelma Maia Souza } \\
\text { Nilma Margarida de Castro Crusoé } \\
\text { Nubia Regina Moreira }\end{array}$ & $\begin{array}{l}\text { Limitações da formação docente evidenciadas na prática } \\
\text { pedagógica: trato com o tema das relações Étnico-Raciais }\end{array}$ & 2016 \\
\hline 06 & $\begin{array}{l}\text { Leandro Passos } \\
\text { Guilherme Costa Garcia Tommaselli } \\
\text { Gilmar Ribeiro Pereira }\end{array}$ & $\begin{array}{l}\text { Mãe de Santo com currículo Lattes: burocracia e enfrentamos } \\
\text { na introdução de práticas pedagógicas que valorizem as } \\
\text { religiões de origem Africana }\end{array}$ & 2016 \\
\hline 07 & $\begin{array}{l}\text { José Valdir Jesus de Santana } \\
\text { Marise de Santana } \\
\text { Marcos Alves Moreira }\end{array}$ & $\begin{array}{l}\text { Cultura, currículo e diversidade etnicorracial: algumas } \\
\text { proposições }\end{array}$ & 2013 \\
\end{tabular}

Tais pesquisas evidenciam a magnitude dos debates sobre as relações étnico-raciais no contexto educativo e a Revista Práxis Educacional não se mostra insuficiente na problematização desse conteúdo, colocando-o sempre em pauta. Isso é salutar, uma vez que essa discussão precisa ser contínua e permanente diante do quadro de violência racial que vivemos.

O segundo periódico com maior quantitativo de publicação na área foi a Revista Exitus, com um total de vinte e nove (29) artigos, disseminados entre os anos de 2012 e 2020. Embora a revista tenha surgido em 2011, a mesma traz uma trajetória bem significativa de publicação sobre a temática. Em 2019, a referida revista apresenta um dossiê temático com nove (09) artigos e uma (01) Conferência com o título Em torno de uma epistemologia preta, realizada por Alexandre Osaniiyi, professor do Instituto Federal de Educação da Bahia - IFBA (OSANIIYI, 2019).

Os artigos que compõem este dossiê se constituem em resultados de investigações que carecem, a cada dia, de mais discussões e debates. Vivemos em uma sociedade racista e o papel da escola é imprescindível para que se construa uma educação que busca pela igualdade racial. Uma educação que preze pela diversidade, sem, contudo, ignorar ou padronizar a diferença. 
Quadro 8 - Dossiê da Revista Exitus.

\begin{tabular}{|c|c|c|c|}
\hline $\mathbf{N}^{\mathbf{o}}$ & AUTORES/AS & TÍTULO DO ARTIGO & ANO \\
\hline 01 & $\begin{array}{l}\text { Mariana Fernandes dos Santos } \\
\text { Flavio Biasutti Valadares } \\
\text { Yuri Miguel Macedo }\end{array}$ & $\begin{array}{l}\text { (Des) Encontros para um currículo afrocentrado no ensino de } \\
\text { língua portuguesa na educação profissional técnica de nível } \\
\text { médio integrada ao ensino médio }\end{array}$ & 2019 \\
\hline 02 & $\begin{array}{l}\text { Rodrigo Fernandes Morais } \\
\text { Antônio Carlos Fontes dos Santos }\end{array}$ & $\begin{array}{l}\text { A importância de um currículo com elementos afrocentrados para } \\
\text { a constituição de uma visão epistemológica menos eurocentrada. }\end{array}$ & 2019 \\
\hline 03 & $\begin{array}{l}\text { Débora Cristina de Araujo } \\
\text { Luís Thiago Freire Dantas }\end{array}$ & Currículo des-oculto: outras vozes, outras epistemologias & 2019 \\
\hline 04 & Ricardo Oliveira de Freitas & Educomunicação como recurso de midiartivismo & 2019 \\
\hline 05 & $\begin{array}{l}\text { Eliana Póvoas Pereira Estrela } \\
\text { Brito }\end{array}$ & $\begin{array}{l}\text { Entre a aceitação e a fuga: a juventude negra em trânsito nos } \\
\text { currículos escolares }\end{array}$ & 2019 \\
\hline 06 & $\begin{array}{l}\text { Dalva de Souza Lobo } \\
\text { Marco Antonio Villarta-Neder } \\
\text { Helena Maria Ferreira }\end{array}$ & Entre omissão e preconceito racial: discurso-acontecimento & 2019 \\
\hline 07 & $\begin{array}{l}\text { Antonio de Assis Cruz Nunes } \\
\text { Luis Félix de Barros Vieira Rocha } \\
\text { Lucileide Martins Borges Ferreira }\end{array}$ & $\begin{array}{l}\text { O Baião de princesas da casa fanti-ashanti: um estudo cromático } \\
\text { no ensino de arte à luz da lei } n^{\circ} 10.639 / 03\end{array}$ & 2019 \\
\hline 08 & Luiz Rufino & Pedagogia das encruzilhadas: Exu como educação & 2019 \\
\hline 09 & $\begin{array}{l}\text { Arlene Santos Silva } \\
\text { Bárbara Carine Soares Pinheiro }\end{array}$ & $\begin{array}{l}\text { Químicxs negros e negras do século XX e o racismo institucional } \\
\text { nas ciências }\end{array}$ & 2019 \\
\hline
\end{tabular}

Conforme demonstra o quadro 8, nesta revista encontram-se dois artigos que defendem a importância de currículo afrocentrado. Os textos (Des)Encontros para um currículo afrocentrado no ensino de língua portuguesa na educação profissional técnica de nível médio integrada ao ensino médio e A importância de um currículo com elementos afrocentrados para a constituição de uma visão epistemológica menos eurocentrada, se fundam em discussões sobre o centralismo epistemológico eurocêntrico e ocidental que se consolidou nas práticas pedagógicas, perpetuando, dessa forma, a colonialidade do saber nas instituições educativas, desconsiderando e/ou silenciando as diferenças culturais, especialmente, dos grupos étnicos negros e indígenas. Nesse contexto, os textos focam no conceito de afrocentricidade como possibilidade de se construir um currículo antirracista e menos colonial (SANTOS; VALADARES; MACEDO, 2019; MORAIS; SANTOS, 2019).

Mais três artigos são destacados, quais sejam: "Currículo des-oculto: outras vozes, outras epistemologias"; "Entre a aceitação e a fuga: a juventude negra em trânsito nos currículos escolares" $e$ "Entre omissão e preconceito racial: discurso-acontecimento". Esses textos expõem as relações étnico-raciais a partir do currículo quer seja no ensino superior, ou na Educação básica, focando nas histórias coloniais que fixam noções de raça, classe e gênero e as relações de poder e seus efeitos sobre os corpos negros (ARAÚJO; DANTAS, 2019; BRITO, 2019; LOBO; VILLARTA-NEDER; FERREIRA, 2019).

Embora o artigo Educomunicação como recurso de midiartivismo não traga em seu título e palavras-chave categorias explicitamente relacionados as relações étnico-raciais, ele analisa 
iniciativas de midiartivismo como práticas educomunicativas e apresenta resultados de análises elaboradas acerca de artistas e coletivos de arte compromissados com ações que promovem discussões sobre temas como gênero, raça e etnia com o intuito de contribuir para o fortalecimento da democracia, a conquista da cidadania e a equidade de direitos. Esses coletivos (artistas, educadores e militantes) fazem uso da mídia e da arte para promover o ativismo, incrementando ações políticas e construindo uma pedagogia das comunidades subalternizadas (FREITAS, 2019).

O pensamento de Gomes (2017) corrobora com a discussão do artigo acima quando a autora assegura que os coletivos, os movimentos negros possuem um valor epistemológico intrínseco, pois, constituem-se em produtos de um tipo específico de conhecimento, qual seja, o conhecimento nascido da luta. O papel desses movimentos como educadores, se constitui na produção de saberes emancipatórios e um sistematizador de conhecimento sobre a questão racial no Brasil. Saberes esses transformados em reinvindicações, das quais várias se tornaram políticas de Estado nas primeiras década do século XXI, rompendo com os processos de colonização incrustados no mundo e na América Latina em especial. Por tudo isso, os movimentos sociais e raciais, os coletivos de artirstas se constituem em movimentos educadores porque gera conhecimento novo.

No artigo $O$ Baião de princesas da casa fanti-ashanti: um estudo cromático no ensino de arte à luz da lei no 10.639/03, retrata o ritual afro-maranhense denominado "Baião de Princesas", na Casa Fanti-Ashanti, na cidade de São Luís. O estudo parte do currículo no ensino de arte à luz da lei no 10.639/03, e torna obrigatório o ensino da história e cultura afro-brasileira e africana na educação básica (NUNES; ROCHA; FERREIRA, 2019).

Para construir outros processos educativos e propostas curriculares antirracistas e decoloniais é que Rufino (2019) lança mão da Pedagogia das encruzilhadas: Exu como Educação. A partir desse projeto político/epistemológico/ético, o autor destaca a importância de uma agenda política que denuncie os vínculos e impactos da colonialidade na educação e proponha formas de transgressão a esse modelo, a partir do fortalecimento de uma educação intercultural e a elaboração de pedagogias decoloniais.

O artigo Químicxs negros e negras do século XX e o racismo institucional nas ciências, tem como objetivo apresentar uma narrativa biográfica da carreira acadêmica e científica de alguns químicxs negros e negras, do Século XX. A luta e a resistência desses cientistas contribuíram para a ampliação do legado afrodescendente no âmbito técnico e científico da humanidade (SILVA; PINHEIRO, 2019). 
Pelos textos apresentados até aqui fica evidenciado que, por inúmeras maneiras, o racismo aflora no sistema educacional. O espaço escolar converteu-se em um local homogêneo e hierarquizado e de controle dos processos de ensino aprendizagem sob o qual se corrigem e normalizam os sujeitos. Essas produções problematizam esta discussão, denuncia situações de preconceito e propõe a construção de uma educação emancipadora, decolonial e afrocentrada.

Ainda no ano de 2019, a Revista Exitus publicou, no volume 09, número 05, oito (08) artigos dedicados a temática relações étnico-raciais. Segue a lista dos artigos no quadro 9 abaixo:

Quadro 09 - Outros artigos sobre a temática relações étnico-raciais na Revista Exitus.

\begin{tabular}{|c|c|c|c|}
\hline $\mathbf{N}^{\mathbf{0}}$ & AUTOR & TÍTULO DO ARTIGO & ANO \\
\hline 01 & $\begin{array}{l}\text { Marcos Antonio Batista da Silva } \\
\text { Maria Sílvia Ribeiro }\end{array}$ & $\begin{array}{l}\text { Diversidade cultural nas políticas públicas: uma análise das leis } \\
10.639 / 03 \text { e } 11.645 / 08\end{array}$ & 2019 \\
\hline 02 & $\begin{array}{l}\text { Iago Vilaça de Carvalho } \\
\text { Bruno Andrade Pinto Monteiro } \\
\text { Fernanda Antunes Gomes da Costa }\end{array}$ & $\begin{array}{l}\text { A lei 10.639/03 no ensino de ciências: uma proposta decolonial } \\
\text { para o currículo de química }\end{array}$ & 2019 \\
\hline 03 & $\begin{array}{l}\text { Anne de Matos Souza Ferreira } \\
\text { Wilma de Nazaré Baía Coelho }\end{array}$ & $\begin{array}{l}\text { Ações dos núcleos de estudos afro-brasileiros (NEABS) } \\
\text { institucionalizados dos institutos federais de educação, ciência e } \\
\text { tecnologia (IFETS) no período de } 2006 \text { a } 2017\end{array}$ & 2019 \\
\hline 04 & $\begin{array}{l}\text { Moema Alves Macêdo } \\
\text { Jefferson de Souza Bernardes }\end{array}$ & $\begin{array}{l}\text { Formação em saúde por meio de vivências em comunidades } \\
\text { tradicionais de matrizes africanas: ressignificando competências }\end{array}$ & 2019 \\
\hline 05 & $\begin{array}{l}\text { Paulo Crispim Alves de Souza } \\
\text { Ivan Fortunato }\end{array}$ & O currículo e as relações étnico-raciais: um território em disputa & 2019 \\
\hline 06 & $\begin{array}{l}\text { Andreza da Paixão Silva } \\
\text { Eliane Miranda Costa }\end{array}$ & $\begin{array}{l}\text { O currículo escolar e as relações étnico-raciais: entre desafios e } \\
\text { perspectivas na educação infantil }\end{array}$ & 2019 \\
\hline 07 & Reginaldo Ferreira Domingos & $\begin{array}{l}\text { Lei } 10.639 / 2003 \text { questões raciais e indenitárias: Uma irrevogável } \\
\text { ação política, um diálogo necessário na educação básica. }\end{array}$ & 2019 \\
\hline 08 & $\begin{array}{l}\text { Mário Luiz de Souza } \\
\text { João Paulo Carneiro }\end{array}$ & $\begin{array}{l}\text { Relações étnico-raciais: Currículo, avaliação, educação e } \\
\text { diversidade }\end{array}$ & 2019 \\
\hline
\end{tabular}
Fonte: Elaborado pelas autoras.

Esses artigos focam a discussão em torno do currículo e as relações raciais como território de disputa, de políticas públicas, a implementação da Lei № 10.639, comunidades tradicionais de matriz africana, bem como as ações dos núcleos de estudos afro-brasileiros. São estudos que discutem as relações étnico-raciais tanto na educação básica e como também no ensino superior. Porém, a centralidade de sua discussão acontece em torno do currículo.

Neste mesmo ano de 2019, no volume 09, nos números 01, 02 e 03, a revista publica mais quatro (04) artigos que abordam o papel do gestor escolar no combate ao racismo, as relações raciais na educação infantil, a afrocentricidade como forma de reinventar a escola a partir da diferença e destaca ainda a efetivação da Lei no 10.639/03, conforme demonstra o quadro 10: 
Quadro 10 - Demais artigos publicados pela Revista Exitus no ano de 2019.

\begin{tabular}{|c|l|l|c|}
\hline $\mathbf{N}^{\mathbf{0}}$ & \multicolumn{1}{|c|}{ AUTOR } & \multicolumn{1}{|c|}{ TÍTULO DO ARTIGO } & ANO \\
\hline 01 & $\begin{array}{l}\text { Helena de Lima Marinho R. Araújo } \\
\text { Aline Cristina Clemente Braga }\end{array}$ & $\begin{array}{l}\text { A escola de todas as cores: o papel do gestor escolar no } \\
\text { combate ao racismo. }\end{array}$ & 2019 \\
\hline 02 & $\begin{array}{l}\text { Jonathas Vilas Boas de Sant'Ana } \\
\text { João Henrique Suanno } \\
\text { Raimundo Márcio Mota de Castro }\end{array}$ & $\begin{array}{l}\text { Afrocentricidade e interculturalidade crítica na educação: } \\
\text { reinventar a escola a partir da diferença }\end{array}$ & 2019 \\
\hline 03 & $\begin{array}{l}\text { José Valdir Jesus de Santana } \\
\text { Rainan Sena Santos Menezes } \\
\text { Reginaldo Santos Pereira }\end{array}$ & $\begin{array}{l}\text { Relações étnico-raciais na educação infantil em Itapetinga- } \\
\text { BA: o que dizem as crianças? }\end{array}$ & 2019 \\
\hline 04 & $\begin{array}{l}\text { Heldina Pereira Pinto Fagundes } \\
\text { Berta Leni Costa Cardoso }\end{array}$ & $\begin{array}{l}\text { Quinze anos de implementação da lei 10.639/2003: desafios } \\
\text { e tensões no contexto da base nacional comum curricular }\end{array}$ & \begin{tabular}{c}
2019 \\
\hline
\end{tabular} \\
\hline
\end{tabular}
Fonte: Elaborado pelas autoras.

Importante evidenciar o artigo A escola de todas as cores: o papel do gestor escolar no combate ao racismo, temática ainda não mencionada até então. O gestor escolar possui uma importante função e precisa estar atento a certos discursos e manifestações racistas presentes na fala de alunos, professores e toda comunidade escolar, lutando no combate ao racismo presente na escola. Assim, este artigo objetivou conhecer o papel do gestor escolar no combate ao racismo nos anos iniciais do Ensino Fundamental (ARAÚJO; BRAGA, 2019). Nesse sentido, faz-se necessário ao gestor, tomar cuidado para não silenciar e muito menos naturalizar as desigualdades étnico-raciais.

Outro artigo que ressaltamos é Relações étnico-raciais na educação infantil em ItapetingaBA: o que dizem as crianças? Neste trabalho os autores buscam compreender como as crianças elaboram sentidos acerca de seus pertencimentos étnico-raciais e como vivenciam e acionam noções como racismo, discriminação racial em suas relações com outras crianças e com os adultos (SANTANA; MENEZES; PEREIRA, 2019).

Vê-se que 2019 foi um ano expressivo para as discussões sobre as relações étnico-raciais na Revsita Exitus, pois esta publicou 21 artigos no total. Apresentamos no quadro 11 mais 08 artigos sobre o assunto relações étnico-raciais.

Quadro 11 - Demais artigos publicados entre os anos de 2012 a 2020 pela Revista Exitus.

\begin{tabular}{|c|c|c|c|}
\hline $\mathbf{N}^{\mathbf{0}}$ & AUTOR & TÍTULO DO ARTIGO & ANO \\
\hline 01 & $\begin{array}{l}\text { Marilza de Oliveira Santos } \\
\text { Francisca Izabel Pereira Maciel }\end{array}$ & $\begin{array}{l}\text { A constituição da identidade negra nos textos e livros didáticos } \\
\text { no ensino fundamental. }\end{array}$ & 2020 \\
\hline 02 & Jeferson Mundim de Souza & $\begin{array}{l}\text { Diálogos e memórias de Luiz Gama e intelectuais negros em } \\
\text { ações políticas e currículos escolares na contemporaneidade }\end{array}$ & 2020 \\
\hline 03 & Iris Verena Oliveira & $\begin{array}{l}\text { "História pra ninar gente grande": } \\
\text { Currículo e formação de professores quilombolas. }\end{array}$ & 2020 \\
\hline 04 & $\begin{array}{l}\text { Benedito Gonçalves Eugenio } \\
\text { Julia Algarra }\end{array}$ & Estudantes cotistas negros e ações afirmativas no ensino superior & 2018 \\
\hline 05 & $\begin{array}{l}\text { Raimundo Santos de Castro } \\
\text { Ademir Donizeti Caldeira }\end{array}$ & $\begin{array}{l}\text { Entrelaçamentos e possibilidades dos jogos de linguagem } \\
\text { Matemáticos: seus usos na comunidade remanescente de } \\
\text { Quilombos da agrovila de espera, Alcântara- MA }\end{array}$ & 2017 \\
\hline
\end{tabular}




\begin{tabular}{|l|l|l|c|}
\hline 06 & $\begin{array}{l}\text { Raquel Amorim dos Santos } \\
\text { Rosângea Maria de Nazaré Barbosa e } \\
\text { Silva } \\
\text { Wilma de Nazaré Baía Coelho }\end{array}$ & $\begin{array}{l}\text { Educação e relações raciais: estado da arte em programas de pós- } \\
\text { graduação em educação (2000-2010). }\end{array}$ & 2014 \\
\hline 07 & $\begin{array}{l}\text { Aparecida das Graças Geraldo } \\
\text { Regina Maria Simões Puccinelli } \\
\text { Tancredi }\end{array}$ & $\begin{array}{l}\text { Políticas de ações afirmativas: uma breve análise do programa de } \\
\text { cotas. }\end{array}$ & 2012 \\
\hline 08 & $\begin{array}{l}\text { Silvina Corbetta } \\
\text { Vanesa D'Alessandre }\end{array}$ & $\begin{array}{l}\text { Educación y afrodescendentes: } \\
\text { Hacia un balance en materia } \\
\text { De políticas educativas }\end{array}$ & 2012 \\
\hline
\end{tabular}

Até o momento de levantamento desses dados (junho de 2020) a revista já publicou três artigos tratando da identidade negra, história de intelectuais negros e mais um artigo sobre currículo e formação docente. Entre os anos de 2012 a 2018, este periódico publicou cinco (05) artigos que tratam desde ações afirmativas, às produções acadêmicas nesta área (estado da arte em programa de pós-graduação), e um artigo internacional, Educación y afrodescendentes: Hacia un balance em materia de políticas Educativas, que objetivou descrever os avanços durante a última década no acesso, permanência e graduação da população afrodescendente do Brasil, bem como compreender os avanços e conflitos entre as políticas educativas e a população afrodescendente, incluindo além do Brasil, Colômbia e República Dominicana (CORBETTA; D’ALESSANDRE, 2012).

A Revista Tempos e Espaços em Educação, embora exista há 12 anos, apresenta 11 artigos entre os anos de 2014 a 2019 sobre o tema pesquisado, os quais estão destacados no quadro 12:

Quadro 12 - Publicações da Revista Tempos e Espaços em Educação.

\begin{tabular}{|c|l|l|c|}
\hline $\mathbf{N}^{\mathbf{0}}$ & \multicolumn{1}{|c|}{ AUTOR } & \multicolumn{1}{c|}{ TÍTULO DO ARTIGO } & ANO \\
\hline 01 & $\begin{array}{l}\text { José Valdir Jesus de Santana } \\
\text { Joanne Oliveira Dias } \\
\text { Reginaldo Santos Pereira } \\
\text { Adenilson Souza Cunha Júnior }\end{array}$ & $\begin{array}{l}\text { "Eu tenho vergonha em dizer que sou negra, ninguém gosta, né"? As } \\
\text { crianças e as relações étnico-raciais em Itapetinga-BA. }\end{array}$ & 2019 \\
\hline 02 & $\begin{array}{l}\text { João Paulo Lopes dos Santos } \\
\text { Núbia Regina Moreira }\end{array}$ & $\begin{array}{l}\text { Articulando currículo, prática e cultura: exigências formativas que } \\
\text { impactam a escolarização de mulheres negras no Ensino Superior } \\
\text { Brasileiro. }\end{array}$ & 2019 \\
\hline 03 & $\begin{array}{l}\text { Paulo Melgaço da Silva Junior } \\
\text { Ana Ivenicki }\end{array}$ & $\begin{array}{l}\text { Entre sexualidades, masculinidades e raça: contribuições do multi/ } \\
\text { interculturalismo para a prática pedagógica }\end{array}$ & 2019 \\
\hline 04 & $\begin{array}{l}\text { Liliana Oliveira da Rocha } \\
\text { Patrícia Ferraz de Matos }\end{array}$ & $\begin{array}{l}\text { Fotografias de Angola do Século XIX: o 'Álbum Fotográfico-Literário' } \\
\text { de Cunha Moraes. }\end{array}$ & 2019 \\
\hline 05 & $\begin{array}{l}\text { Carina Viviana Kaplan } \\
\text { Nubea Rodrigues Xavier }\end{array}$ & $\begin{array}{l}\text { As Infâncias na literatura latino-americana: quais os lugares da menina } \\
\text { e da mulher negras? }\end{array}$ & 2018 \\
\hline 06 & $\begin{array}{l}\text { Lucas Colangeli de Souza } \\
\text { Maria de Fátima Di Gregório }\end{array}$ & $\begin{array}{l}\text { Ensaio sobre a História e Cultura Afro-Brasileira e Indígena } \\
\text { Trabalhadas nas Salas de Aulas do Ensino Fundamental das Escolas } \\
\text { Públicas no Nordeste do Brasil: Entre Desafios dos Livros Didáticos e } \\
\text { Docência }\end{array}$ & 2016 \\
\hline 07 & $\begin{array}{l}\text { Benedito Gonçalves Eugênio } \\
\text { Andirana Oliveira Lima }\end{array}$ & $\begin{array}{l}\text { Imagens de negros e negras no livro didático de história dos anos } \\
\text { iniciais do ensino fundamental }\end{array}$ & 2015 \\
\hline 08 & Maria Mary Ferreira & $\begin{array}{l}\text { Relações de Classe e Gênero na Escola: revisitando conceitos de } \\
\text { igualdade, desigualdade, diferença, classe e gênero. }\end{array}$ & 2014 \\
\hline
\end{tabular}




\begin{tabular}{|c|l|l|c|}
\hline 09 & $\begin{array}{l}\text { Maria da Anunciação } \\
\text { Conceição Silva }\end{array}$ & $\begin{array}{l}\text { Formação docente: do infinito ao particular! Narrativas sobre gênero, } \\
\text { raça e religião }\end{array}$ & 2014 \\
\hline 10 & Liliane Pereira de Souza & Educação, gênero e raça: Mapeando algumas desigualdades & 2014 \\
\hline 11 & $\begin{array}{l}\text { Máira Conceição Alves } \\
\text { Pereira } \\
\text { Stela Guedes Caputo }\end{array}$ & $\begin{array}{l}\text { Dialogando com narrativas digitais e aprendizagens nos terreiros de } \\
\text { candomblé }\end{array}$ & 2014 \\
\hline
\end{tabular}

Fonte: Elaborado pelas autoras.

Os anos em que houve maior produção da temática pesquisada foram de 2014 a 2019, com quatro (04) artigos cada, seguindo no período de 2015, 2016 e 2018, com um artigo por ano. Essas produções trazem uma variedade de conteúdos que vão desde as relações étnico-raciais, currículo, o negro no livro didático, até raça e sexualidade e imagens fotográficas. Destacaremos para análise quatro artigos que tratam mais diretamente das relações raciais e a educação básica.

O artigo "Eu tenho vergonha em dizer que sou negra, ninguém gosta, né"? As crianças e as relações étnico-raciais em Itapetinga-BA, demonstra como as crianças agem, acionam e vivenciam as noções de racismo e discriminação racial na relação com os pares, bem como com os adultos, buscando compreender o que significa, para as crianças, pertencer a uma categoria racial (branco e não branco) e como elas lidam com essas categorias. A pesquisa conclui que as crianças, "mesmo sem entender como o racismo as afetavam, já estavam, cotidianamente, propagando-o a partir de suas práticas, mesmo que sem intenção". Outro fator que os autores imprimem "é que algumas crianças, mesmo expressando que ser negro não é bom, contentam-se com essa condição e utilizam o argumento de que todo mundo é filho de Deus" (SANTANA et all, 2019, p. 340).

Ressoam na nossa sociedade, na escola e nas pedagogias empregadas no contexto escolar, posições marcadamente racistas. Não são raras as situações de discriminação que as crianças enfrentam. Diante disso, é preciso investir mais na educação para as relações étnico-raciais, especialmente entre as crianças menores.

O texto Articulando currículo, prática e cultura: exigências formativas que impactam a escolarização de mulheres negras no Ensino Superior Brasileiro, reflete sobre os impactos das práticas curriculares na escolarização de mulheres negras na academia. Esta discussão corrobora com alguns artigos que discutem currículo e colonialidade na Revista Exitus, bem como, a subjetivação da mulher negra, vista em artigos da Revista Práxis Educacional.

$\mathrm{O}$ artigo Ensaio sobre a história e cultura afro-brasileira e indígena trabalhadas nas salas de aulas do ensino fundamental das escolas públicas no nordeste do Brasil: entre desafios dos livros didáticos e docência, problematiza os conteúdos expressos nos livros didáticos utilizados nas salas de aulas os quais exprimem as marcas dos processos hegemônicos de colonização do país (SOUZA; 
DI GREGÓRIO, 2016). Já o texto Imagens de negros e negras no livro didático de história dos anos iniciais do ensino fundamental, apresenta os resultados de uma investigação que buscou compreender de que forma os conteúdos sobre o negro são tratados no livro didático de História (EUGÊNIO; LIMA, 2015). Essas duas discussões corroboram com o estudo de Ana Célia Silva (2010) que, na década de 1990, desenvolveu uma pesquisa sobre a representação do negro nos livros didáticos e chegou à conclusão de que quase sempre os livros caracterizavam o negro de forma desumanizada, estigmatizada e estereotipada.

A produção Dialogando com narrativas digitais e aprendizagens nos terreiros de candomblé aborda as redes educativas entrelaçadas, cotidianamente, com as religiões de matriz africana. Essas redes educativas formam processos pedagógicos específicos, e nelas os sujeitos se modificam, contribuindo para as mudanças que se processam em fluxo e cotidianamente. Este trabalho, em sua potência criadora, confere mais visibilidade para a religião e contribui para a superação do preconceito e fortalecimento de identidades (PEREIRA; CAPUTO, 2014).

Os demais artigos publicados pela revista mantêm uma importante relação ao discutir categorias como gênero e raça; classe e gênero; igualdade e desigualdade; gênero, raça e religião; sexualidade, masculinidade e raça, categorias estas relacionadas à educação. Cada texto à sua maneira, traz resultados de pesquisas que focam em compreender as desigualdades sociais, raciais e de gênero que se estabelecem na nossa sociedade e nas instituições educativas. Essas diferenças precisam ser pensadas como projeto social que visa construir uma educação democrática, possibilitando, assim, a redução das desigualdades. Nesse sentido, faz-se necessário problematizar e refletir com os docentes suas experiências acerca das questões raciais, de classe, de gênero, de sexualidade e de religião no cotidiano das suas práticas pedagógicas.

Nas publicações de uma forma geral, nota-se que algumas temáticas são mais recorrentes, tais como o currículo, a Lei no 10.639 de 2003 e a obrigatoriedade do ensino sobre a história da África, formação de professor e as relações raciais. No entanto, estudos e pesquisas sobre as relações étnico-raciais na educação infantil ainda é são escassos. Dos 74 artigos, apenas duas pesquisas abordam sobre as relações étnico-raciais na educação infantil.

\section{CONSIDERAÇÕES FINAIS}

Este artigo objetivou mapear e analisar as produções acadêmicas nas revistas Revista Educação \& Formação, Revista Exitus, Revista Práxis Educacional e Revista Tempos e Espaços em 
Educação da região Norte e Nordeste, destacando o dialogo étnico-racial em interface com a educação dentro do recorte temporal de 2010-2020, ou seja, um período de 10 anos.

Foram catalogados setenta e quatro (74) artigos publicados em quatro (04) revistas das regiões Norte e Nordeste do país. Foi perceptível que no decorrer de 10 anos os periódicos trouxeram importantes contribuições na divulgação de pesquisas sobre as relações étnico-raciais e a educação. O marcador étnico-raciais e sua interseção com a educação permite entender que essas questões se encontram enredadas numa teia de poder sobre o corpo negro.

Entretanto, a exitosa produção, bem como a sua carência (em alguns periódicos) devem servir de mola propulsora para o surgimento de novos estudos sobre as questões raciais, que fortaleçam o combate ao racismo e o preconceito étnico racial que ainda se encontram engessados em alguns contextos educacionais brasileiros, bem como nas entranhas das estruturas sociais deste país. Especialmente, neste momento histórico de revogação de leis que garantem o acesso das pessoas negras às instituições educativas.

É necessário repensar o modelo de sociedade que temos e queremos, bem como a escola e as suas práticas, fazendo-as ir ao encontro dos interesses coletivos, promovendo a valorização dos saberes e laços culturais de seus sujeitos. Não nos furtemos de protagonizar uma educação que garanta uma cultura de paz e respeito, que dissipe as agruras de uma sociedade racista.

\section{REFERÊNCIAS}

AMADO, João da Silva. Construir a disciplina para um ensino de qualidade. Revista Práxis Educacional, Vitória da Conquista, v.4, n. 5, jun./dez. 2008. Disponível em:

http://periodicos2.uesb.br/index.php/praxis/article/view/574. Acesso em: 12 fev. 2020.

ARAÚJO, Débora Cristina de; DANTAS, Luís Thiago Freire. Currículo des-oculto: outras vozes, outras epistemologias. Revista Exitus, Santarém-PA, v. 9, n. 4, p. 147-175, 2019. Disponível em:

http://www.ufopa.edu.br/portaldeperiodicos/index.php/revistaexitus/article/view/1015/531.

Acesso em: 05 jul. 2020. DOI: https://doi.org/10.24065/2237-9460.2019v9n4ID1015.

ARAÚJO, Helena de Lima Marinho Rodrigues; BRAGA, Aline Cristina Clemente. A escola de todas as cores: o papel do gestor escolar no combate ao racismo. Revista Exitus, Santarém-PA, v. 9, n. 2, p. 263-291, 2019. Disponível em:

http://www.ufopa.edu.br/portaldeperiodicos/index.php/revistaexitus/article/view/863/444. Acesso em: 05 de jul. 2020. DOI: https://doi.org/10.24065/2237-9460.2019v9n2ID863.

ASSOLINI, Filomena Elaine Paiva. Professoras alfabetizadoras e suas leituras: história, memória e prática pedagógica escolar. Revista Práxis Educacional, Vitória da Conquista, v. 6, n. 8, jan./jun. 2010. Disponível em: http://periodicos2.uesb.br/index.php/praxis/article/view/616. Acesso em: 14 fev. 2020. 
BARBOSA, Lia Pinheiro; ROSSET, Peter Michael. Movimentos Sociais e Educação do Campo na América Latina: aprendizagens de um percurso histórico. Revista Práxis Educacional, Vitória da Conquista, v.13, n. 26, set./dez. 2017. Disponível em:

http://periodicos2.uesb.br/index.php/praxis/article/view/2819. Acesso em: 12 fev. 2020.

BRASIL. Lei no 11.645, de 10 março de 2008. Disponível em: http://www.planalto.gov.br/ccivil 03/ Ato2007-2010/2008/Lei/L11645.htm. Acesso em: 06 jul. 2020.

BRASIL. Lei $\mathbf{n}^{\circ} \mathbf{1 0 . 6 3 9}$, de 9 de janeiro de 2003. Disponível em: http://www.planalto.gov.br/ccivil 03/leis/2003/l10.639.htm. Acesso em: 06 jul. 2020.

BRITO, Eliana Póvoas Pereira Estrela. Entre a aceitação e a fuga: a juventude negra em trânsito nos currículos escolares. Revista Exitus, Santarém-PA, v. 9, n. 4, p. 37-65, 2019. Disponível em: http://www.ufopa.edu.br/portaldeperiodicos/index.php/revistaexitus/article/view/1004/522. Acesso em: 06 jul. 2020. DOI: https://doi.org/10.24065/2237-9460.2019v9n4ID1004.

BRITO, Regivane dos Santos; PRADO, Jany Rodrigues; NUNES, Claudio Pinto. As condições de trabalho docente e o pós-estado de bem-estar social. Revista Tempos e Espaços em Educação (online), v. 10, p. 165-174, 2017. Disponível em:

https://seer.ufs.br/index.php/revtee/article/view/6676. Acesso em: 21 fev. 2020.

CARDOSO, Ivanilda Amado e CASTRO, Rosane Michelli de. A ausência/presença das relações étnico-raciais nos currículos dos cursos de pedagogia: o caso da Unesp/Marília. Revista Práxis Educacional, Vitória da Conquista - BA, v. 11, n. 18, p. 91-115, 2015. Disponível em: http://periodicos2.uesb.br/index.php/praxis/article/view/802/679. Acesso em: 06 jul. 2020.

CASTRO NETA, Abília Ana de; CARDOSO, Berta Leni Costa, NUNES, Claudio Pinto. Reformas educacionais no contexto pós-golpe de 2016. Revista Educação em Debate, Fortaleza, v. 40, p. 162-174, 2018. Disponível em:

http://www.periodicosfaced.ufc.br/index.php/educacaoemdebate/article/view/703. Acesso em: 17 fev. 2020.

COELHO, Wilma de Nazaré Baía; BRITO, Nicelma Josenila Costa de. Dez anos da lei n. 10.639/2003 e a formação de professores e relações raciais em artigos (2003/2013): um tema em discussão.

Revista Práxis Educacional, Vitória da Conquista - BA, v. 16, n. 39, p. 19-42, 2020. Disponível em: http://periodicos2.uesb.br/index.php/praxis/article/view/6358/4691. Acesso em: 06 jul. 2020. DOI: https://doi.org/10.22481/praxisedu.v16i39.6358.

CORBETTA, Silvina e D'ALESSANDRE, Vanesa. Educación y afrodescendentes: Hacia un balance em materia de políticas Educativas. Revista Exitus, Santarém-PA, v. 02, n. 01, p.57-77, 2012.

Disponível em:

http://ufopa.edu.br/portaldeperiodicos/index.php/revistaexitus/article/view/64/64. Acesso em: 06 jul. 2020.

COSTA, Ana Sheila Fernandes; AKKARI, Abdeljalil; SILVA, Rossana Valéria Souza. Educação básica no Brasil: políticas públicas e qualidade. Revista Práxis Educacional, Vitória da Conquista, v.7, n. 
11, jun./dez. 2011. Disponível em: http://periodicos2.uesb.br/index.php/praxis/article/view/666. Acesso em: 14 fev. 2020.

CRUZ, Maria Helena Santana. A Crítica Feminista à Ciência e Contribuição à Pesquisa nas Ciências Humanas. Revista Tempos e Espaços em Educação, São Cristóvão - SE, v. 7, n. 12, p. 15-28, 2014. Disponível em: https://seer.ufs.br/index.php/revtee/article/view/2949/2596. Acesso em: 07 jul. 2020. DOI: https://doi.org/10.20952/revtee.v0i0.2949.

DIAS, Alfrancio Ferreira. Como as escolas educam corpos nas práticas pedagógicas?. Revista Tempos e Espaços em Educação, São Cristóvão - SE, v. 7, n. 12, p. 103-112, 2014. Disponível em: https://seer.ufs.br/index.php/revtee/article/view/2958/2603. Acesso em: 07 jul. 2020. DOI: https://doi.org/10.20952/revtee.v0i0.2958.

DIAS, Alfrancio Ferreira; MENEZES, Carlos André Araújo. Que inovação pedagógica a pedagogia queer propõe ao currículo escolar?. Revista Tempos e Espaços em Educação, São Cristóvão - SE, v. 10, n. 23, p. 37-48, 2017. Disponível em: https://seer.ufs.br/index.php/revtee/article/view/7443. Acesso em: 07 jul. 2020. DOI: https://doi.org/10.20952/revtee.v10i23.7443.

DUARTE, Alexandre William Barbosa; OLIVEIRA, Dalila Andrade. Valorização profissional docente nos sistemas de ensino de Minas Gerais e Pernambuco. Revista Práxis Educacional, Vitória da Conquista, v.10, n. 17, jun./dez. 2014. Disponível em:

http://periodicos2.uesb.br/index.php/praxis/article/view/780. Acesso em: 12 fev. 2020.

EUCLIDES, Maria Simone; SILVA, Joselina da. Dialogando autoetnografias negras: intersecções de vozes, saberes e práticas docentes. Revista Práxis Educacional, Vitória da Conquista - BA, v. 15, n. 32, p. 33-52, 2019. Disponível em: Acesso em:

http://periodicos2.uesb.br/index.php/praxis/article/view/5042/3911. Acesso em: 07 jul. 2020. DOI: https://doi.org/10.22481/praxis.v15i32.5042.

EUGÊNIO, Benedito Gonçalves; LIMA, Andirana Oliveira. Imagens de negros e negras no livro didático de história dos anos iniciais do ensino fundamental. Revista Tempos e Espaços em Educação, São Cristóvão - SE, v. 8, n. 16, p. 247-256, 2015. Disponível em: https://seer.ufs.br/index.php/revtee/article/view/3964/3320. Acesso em: 07 jul. 2020. DOI: https://doi.org/10.20952/revtee.v0i0.3964.

EUGÊNIO, Benedito Gonçalves. O currículo na educação de jovens e adultos: entre o formal e o cotidiano numa escola municipal em belo horizonte. Revista Práxis Educacional, Vitória da Conquista, v. 4, n. 4, jan./jun. 2008. Disponível em: https://periodicos2.uesb.br/index.php/praxis/article/view/570. Acesso em: 14 fev. 2020.

FARIA, Edite Maria da Silva de. O percurso formativo dos professores/pesquisadores da EJA na contemporaneidade. Revista Práxis Educacional, Vitória da Conquista, v. 5, n. 7, jan./jun. 2009. Disponível em: http://periodicos2.uesb.br/index.php/praxis/article/view/607. Acesso em: 10 fev. 2020.

FERNANDES, Maria José da Silva; BARBOSA, Andreza. O trabalho docente na rede pública do estado de São Paulo: apontamentos iniciais para a discussão da jornada de trabalho. Revista 
Práxis Educacional, Vitória da Conquista, v.10, n. 11, jun./dez. 2014. Disponível em: http://periodicos2.uesb.br/index.php/praxis/article/view/782. Acesso em: 13 fev. 2020.

FINO, Carlos Nogueira. Inovação Pedagógica e Ortodoxia Curricular. Revista Tempos e Espaços em Educação, São Cristóvão - SE, v. 9, n. 18, p. 13-22, 14 abr. 2016. Disponível em: https://seer.ufs.br/index.php/revtee/article/view/4959/4094. Acesso em: 07 jul. 2020. DOI: https://doi.org/10.20952/revtee.v9i18.4959.

FREIRA, Maria Auxiliadora S. Práxis pedagógica e professores intelectuais: refletindo as tensões e concepções da formação/prática docente. Revista Práxis Educacional, Vitória da Conquista, v.1, n. 1, jan./dez. 2005. Disponível em: http://periodicos2.uesb.br/index.php/praxis/article/view/485. Acesso em: 13 fev. 2020.

FREITAS, Ricardo Oliveira de. Educomunicação como recurso de midiartivismo. Revista Exitus, Santarém-PA, v. 9, n. 4, p. 232-261, 2019. Disponível em:

http://www.ufopa.edu.br/portaldeperiodicos/index.php/revistaexitus/article/view/1011/527. Acesso em: 07 jul. 2020. DOI: https://doi.org/10.24065/2237-9460.2019v9n4ID1011.

GOMES, Nilma Lino. O Movimento Negro Educador: saberes construídos nas lutas emancipatórias. Petrópolis, RJ: Vozes, 2017.

GOMES-DA-SILVA, Pierre Normando. Pedagogia da corporeidade: o decifrar e o subjetivar na educação. Revista Tempos e Espaços em Educação, São Cristóvão - SE, v. 7, n. 13, p. 15-30, 2014. Disponível em: https://seer.ufs.br/index.php/revtee/article/view/3255/2874. Acesso em: 07 jul. 2020. DOI: https://doi.org/10.20952/revtee.v0i0.3255.

GUIMARÃES, Antonio Sergio A. A Democracia racial: o ideal, o pacto e o mito. In: Novos Estudos: CEBRAP. n. 61, p. 141-162, 2001. Disponível em: http://novosestudos.uol.com.br/produto/edicao61/. Acesso em: 07 jul. 2020.

ILHA, Franciele Roos da Silva; HYPOLITO, Álvaro Moreira. O trabalho docente no início da carreira e sua contribuição para o desenvolvimento profissional do professor. Revista Práxis Educacional, Vitória da Conquista, v.10, n. 17, jun./dez. 2014. Disponível em: http://periodicos2.uesb.br/index.php/praxis/article/view/781. Acesso em: 11 fev. 2020.

KOVACS, Helena; TINOCA, Luís. Unfreeze the pedagogies: introduction of a new innovative measure in Portugal. Revista Tempos e Espaços em Educação, São Cristóvão - SE, v. 10, n. 23, p. 73-86, 2017. Disponível em: https://seer.ufs.br/index.php/revtee/article/view/7446/pdf. Acesso em: 07 jul. 2020. DOI: https://doi.org/10.20952/revtee.v10i23.7446

LOANGO, Anny Ocoró. Emancipación y descolonización: tensiones, luchas y aprendizajes de los investigadores/as negros/as en la educación superior. Revista Práxis Educacional, Vitória da Conquista - BA, v. 15, n. 32, p. 53-68, 2019. Disponível em: http://periodicos2.uesb.br/index.php/praxis/article/view/5043/3912. Acesso em: 07 jul. 2020. DOI: $\underline{\text { https://doi.org/10.22481/praxis.v15i32.5043 }}$

LOBO, Dalva de Souza; VILLARTA-NEDER, Marco Antônio; FERREIRA, Helena Maria. Entre omissão e preconceito racial: discurso-acontecimento. Revista Exitus, Santarém-PA, v. 9, n. 4, p. 176-203, 
2019. Disponível em:

http://www.ufopa.edu.br/portaldeperiodicos/index.php/revistaexitus/article/view/1009/525.

Acesso em: 07 jul. 2020. DOI: https://doi.org/10.24065/2237-9460.2019v9n4ID1009

MARINHO, Thais Alves. Educação quilombola: entre o mito e o fato. Revista Práxis Educacional, Vitória da Conquista - BA, v. 11, n. 18, p. 65-89, 2015. Disponível em:

http://periodicos2.uesb.br/index.php/praxis/article/view/801/678. Acesso em: 06 jul. 2020.

MARQUES, Eugenia Portela de Siqueira; RIBEIRO, Maria Aparecida Pereira dos Santos. Quais as implicações para o fortalecimento da identidade negra no contexto da educação superior?,

Revista Práxis Educacional, Vitória da Conquista - BA, v. 15, n. 32, p. 205-224, 2019. Disponível em: http://periodicos2.uesb.br/index.php/praxis/article/view/5051/3919. Acesso em: 07 jul. 2020.

DOI: https://doi.org/10.22481/praxis.v15i32.5051.

MARQUES, Janote Pires. Além da história, a tradição oral: Considerações sobre o ensino de história da África na educação básica. Revista Educação \& Formação, Fortaleza - CE, v. 2, n. 5, p. 164-182, maio/ago. 2017. Disponível em: Acesso em:

https://revistas.uece.br/index.php/redufor/article/view/142/125. Acesso em: 07 jul. 2020. DOI: https://doi.org/10.25053/edufor.v2i5.1929.

MENEZES, Carlos André Araújo; DIAS, Alfrancio Ferreira; SANTOS, Madson de Santana. What pedagogical innovation does queer pedagogy propose to the school curriculum?. Práxis Educacional, Vitória da Conquista - BA, v. 16, n. 37, p. 241-258, jan. 2020. Disponível em: http://periodicos2.uesb.br/index.php/praxis/article/view/6168/4590. Acesso em: 05 jul. 2020. DOI: https://doi.org/10.22481/praxisedu.v16i37.6168.

MIRANDA, Claudia et all. Presença de mulheres negras na pesquisa em educação: conversas sobre o estágio docente. Revista Práxis Educacional, Vitória da Conquista - BA, v. 15, n. 32, p. 132-154, 2019. Disponível em: http://periodicos2.uesb.br/index.php/praxis/article/view/5047/3916. Acesso em: 07 jul. 2020. DOI: https://doi.org/10.22481/praxis.v15i32.5047.

MORAIS, Rodrigo Fernandes; SANTOS, Antônio Carlos Fontes dos. A importância de um currículo com elementos afrocentrados para a constituição de uma visão epistemológica menos eurocentrada. Revista Exitus, Santarém-PA, v. 9, n. 4, p. 66-94, 2019. Disponível em: http://www.ufopa.edu.br/portaldeperiodicos/index.php/revistaexitus/article/view/1005/523. Acesso em: 05 jul. 2020. DOI: https://doi.org/10.24065/2237-9460.2019v9n4ID1005.

MOREIRA Núbia Regina, EVANGELISTA, Nadila Jardim, SANTOS, João Paulo Lopes dos. A experiência feminina negra e suas interrogações à política e prática curriculares. Revista Práxis Educacional, Vitória da Conquista - BA, v. 15, n. 32, p. 115-131, 2019. Disponível em: http://periodicos2.uesb.br/index.php/praxis/article/view/5046/3915. Acesso em: 07 jul. 2020. DOI: $\underline{\text { https://doi.org/10.22481/praxis.v15i32.5046 }}$

MOREIRA, Antonio Flávio; SILVA JÚNIOR, Paulo Melgaço da. Currículo, Transgressão e Diálogo: quando Outras Possibilidades se Tornam Necessárias. Revista Tempos e Espaços em Educação, São Cristóvão - SE, v. 9, n. 18, p. 45-54, 2016. Disponível em:

https://seer.ufs.br/index.php/revtee/article/view/4962/4097. Acesso em: 07 jul. 2020. DOI: https://doi.org/10.20952/revtee.v9i18.4962. 
MORGADO, José Carlos. O professor como decisor curricular: de ortodoxo a cosmopolita. Revista Tempos e Espaços em Educação, São Cristóvão - SE, v. 9, n. 18, p. 55-64, 2016. Disponível em: https://seer.ufs.br/index.php/revtee/article/view/4964/4098. Acesso em: 07 jul. 2020. DOI: https://doi.org/10.20952/revtee.v9i18.4964.

NASCIMENTO, L. F.; CAVALCANTE, M. M. D. Abordagem quantitativa na pesquisa em educação: investigações no cotidiano escolar. Revista Tempos e Espaços em Educação, v. 11, n. 25, p. 249260, 29 mar. 2018. Disponível em: https://seer.ufs.br/index.php/revtee/article/view/7075 Doi: https://doi.org/10.20952/revtee.v11i25.7075

NUNES, Antonio de Assis Cruz; ROCHA, Luis Félix de barros Vieira e FERREIRA, Lucileide Martins Borges. O Baião de princesas da casa fanti-ashanti: um estudo cromático no ensino de arte à luz da lei no 10.639/03. Revista Exitus, Santarém-PA, Vol. 9, N 4, p. 95-120, 2019. Disponível em: http://ufopa.edu.br/portaldeperiodicos/index.php/revistaexitus/article/view/1013/529. Acesso em: 06 jul. 2020. DOI: https://doi.org/10.24065/2237-9460.2019v9n4ID1013

NUNES, Claudio Pinto. Formación y trabajo docente: cuestiones contemporáneas. Revista Êxitus, Santarém, v. 9, n. 1, 2019. Disponível em:

http://www.ufopa.edu.br/portaldeperiodicos/index.php/revistaexitus/article/view/917. Acesso em: 18 fev. 2020.

NUNES, Claudio Pinto; OLIVEIRA, Dalila Andrade. Trabalho, carreira, desenvolvimento docente e mudança na prática educativa. Educação e Pesquisa, São Paulo, v. 43, p. 65-80, 2017. Disponível em: https://www.scielo.br/scielo.php?pid=S1517-

97022017000100066\&script=sci abstract\&tlng=pt. Acesso em: 20 fev. 2020.

OLIVEIRA, Eliane Guimarães de; SILVA, Daniela Oliveira Vidal da; BRITO, Vera Lúcia Fernandes de; NUNES, Claudio Pinto. Desenvolvimento profissional docente: um olhar para além da formação.

Educa - Revista Multidisciplinar em Educação, v. 5, p. 23-39, 2018. Disponível em:

https://www.periodicos.unir.br/index.php/EDUCA/article/view/3254. Acesso em: 20 fev. 2020.

OLIVEIRA, JOÃO Leandro de Cássio de; NUNES, Claudio Pinto. A carreira docente nos Institutos Federais em comparação com outras escolas públicas. Revista Educação e Emancipação, São Luís, v. 10, n. 2, maio/ago. p. 185-204, 2017. Disponível em:

http://www.periodicoseletronicos.ufma.br/index.php/reducacaoemancipacao/article/view/7393. Acesso em: 22 ago. 2019.

OLIVEIRA, Iris Verena. Narrativa de práticas docentes como intelectual negra: invenções e rasuras.

Revista Práxis Educacional, Vitória da Conquista - BA, v. 15, n. 32, p. 89-114, 2019. Disponível em: http://periodicos2.uesb.br/index.php/praxis/article/view/5045/3914. Acesso em: 06 jul. 2020. DOI: $\underline{\text { https://doi.org/10.22481/praxis.v15i32.5045 }}$

OLIVEIRA, Lívia Maria Serafim Duarte; ARAGÃO, Patrícia Cristina de. As questões étnico-raciais nas histórias em quadrinhos e as práticas educativas na formação inicial docente. Revista Educação \& Formação, v. 3, n. 8, p. 171-190, 2018. Disponível em:

https://revistas.uece.br/index.php/redufor/article/view/276/204. Acesso em: 06 jul. 2020.

DOI: https://doi.org/10.25053/redufor.v3i8.276. 
OLIVEIRA, Luiz Fernandes de. Concepções docentes sobre as relações étnico-raciais em educação e a Lei 10.639/03. Revista Práxis Educacional, Vitória da Conquista - BA, v. 11, n. 18 p. 43-64, 2015. Disponível em: http://periodicos2.uesb.br/index.php/praxis/article/view/800/677. Acesso em: 06 jul. 2020.

ONOFRE, Joelson Alves. Repensando a questão curricular: caminho para uma educação antiracista. Revista Práxis Educacional. Vitória da Conquista - BA, v. 4, n. 4, p. 103-122, jan./jun. 2008. Disponível em http://periodicos2.uesb.br/index.php/praxis/article/view/563/457. Acesso em: 06 jul. 2020.

OSANIIYI, Alexandre. Conferência: Em torno de uma epistemologia preta. Revista Exitus, Santarém-PA, v. 9, n. 4, p. 17 - 36, out/dez 2019. Disponível em:

http://www.ufopa.edu.br/portaldeperiodicos/index.php/revistaexitus/article/view/1003/521.

Acesso em: 06 jul. 2020. DOI: https://doi.org/10.24065/2237-9460.2019v9n4ID1003

PACHECO, José Augusto; SOUSA, Joana. O (pós) crítico na Desconstrução Curricular. Revista Tempos e Espaços em Educação, São Cristóvão - SE, v. 9, n. 18, p. 65-74, 2016. Disponível em: https://seer.ufs.br/index.php/revtee/article/view/4971/4105. Acesso em: 07 jul. de 2020. DOI: https://doi.org/10.20952/revtee.v9i18.4971.

PARASKEVA, J. M. "Brutti, Sporchi \& Cattivi": Towards a Non-Abyssal Curriculum. Revista Tempos e Espaços em Educação, v. 9, n. 18, p. 75-90, 2016. Disponível em:

https://seer.ufs.br/index.php/revtee/article/view/4966 Doi:

https://doi.org/10.20952/revtee.v9i18.4966

PEDRO, Neuza. Ambientes educativos inovadores: o estudo do fator espaço nas 'salas de aula do futuro' portuguesas. Revista Tempos e Espaços em Educação, São Cristóvão - SE, v. 10, n. 23, p. 99-108, 2017. Disponível em: https://seer.ufs.br/index.php/revtee/article/view/7448. Acesso em: 07 jul. de 2020. DOI: https://doi.org/10.20952/revtee.v10i23.7448.

PEREIRA, Máira Conceição Alves; CAPUTO, Stela Guedes. Dialogando com narrativas digitais e aprendizagens nos terreiros de candomblé. Revista Tempos e Espaços em Educação, São Cristóvão - SE, v. 7, n. 14, p. 45-52, 2014. Disponível em:

https://seer.ufs.br/index.php/revtee/article/view/3450/3013 Acesso em: 07 jul. 2020.

DOI: https://doi.org/10.20952/revtee.v0i0.3450

PEREZ, Marcia Cristina Argenti. Infância e escolarização: discutindo a relação família, escola e as especificidades da infância na escola. Revista Práxis Educacional, Vitória da Conquista, v. 8, n. 12, jan./jun. 2012. Disponível em: http://periodicos2.uesb.br/index.php/praxis/article/view/684. Acesso em: 15 fev. 2020. 
RIBEIRO, Júlia Cecília de Oliveira Alves; SILVA, Daniela Oliveira Vidal da; CARDOSO, Elisângela Andrade Moreira; NUNES, Claudio Pinto. A educação do campo em tempos de privatização e golpe. Revista Cenas Educacionais, Caetité, v. 1, p. 111-128, 2018. Disponível em:

https://www.revistas.uneb.br/index.php/cenaseducacionais/article/view/5141. Acesso em: 21 fev. 2020.

SILVA, Daniela Oliveira Vidal da; BRITO, Vera Lúcia Fernandes de; NUNES, Claudio Pinto. Valorização docente na conjuntura do pós impeachement de 2016 no Brasil. Revista Cocar (online), v. 13, p. 1-20, maio/ago. 2019. Disponível em:

https://periodicos.uepa.br/index.php/cocar/article/view/2518. Acesso em: 19 fev. 2020.

ROMANOWSKI, Joana Paulin; ENS, Romilda Teodora. As pesquisas denominadas do tipo "Estado da Arte" em educação. Revista Diálogo Educação, v. 6, n.19, p.37-50, 2006. Disponível em: https://periodicos.pucpr.br/index.php/dialogoeducacional/article/view/24176. Acesso em: 06 jul. 2020.

RUDD, Tim; GOODSON, Ivor F. Refraction as a tool for understanding action and educational orthodoxy and transgression. Revista Tempos e Espaços em Educação, São Cristóvão - SE, v. 9, n. 18, p. 99-110, 2016. Disponível em: https://seer.ufs.br/index.php/revtee/article/view/4968. Acesso em: 07 jul. 2020. DOI: https://doi.org/10.20952/revtee.v9i18.4968.

RUFINO, Luiz. Pedagogia das Encruzilhadas: Exu como Educação. Revista Exitus, Santarém-PA, v. 9, n. 4, p. 262-289, 2019. Disponível em:

http://www.ufopa.edu.br/portaldeperiodicos/index.php/revistaexitus/article/view/1012/528. Acesso em: 06 jul. 2020. DOI: https://doi.org/10.24065/2237-9460.2019v9n4ID1012

SANTANA, José Valdir Jesus de et all. "Eu tenho vergonha em dizer que sou negra, ninguém gosta, né"? As crianças e as relações étnico-raciais em Itapetinga-BA. Revista Tempos e Espaços em Educação, São Cristóvão - SE, v. 12, n. 28, p. 323-346, 2019. Disponível em:

https://seer.ufs.br/index.php/revtee/article/view/9982/pdf. Acesso em: 06 jul. 2020.

DOI: https://doi.org/10.20952/revtee.v12i28.9982.

SANTANA, José Valdir Jesus de; MENEZES, Rainan Sena Santos; PEREIRA, Reginaldo Santos. Relações étnico-raciais na Educação Infantil em Itapetinga-Ba: o que dizem as crianças? Revista Exitus, Santarém-PA, v. 9, n. 1, p. 367-396, 2019. Disponível em: http://www.ufopa.edu.br/portaldeperiodicos/index.php/revistaexitus/article/view/727/427. Acesso em: 06 jul. 2020. DOI: https://doi.org/10.24065/2237-9460.2019v9n1ID727.

SANTOS, Kátia Silva; BAPTISTA, Claudio Roberto. Novos 'referenciais' cognitivos e normativos para a política nacional de educação especial no Brasil. Revista Práxis Educacional, Vitória da Conquista, v.10, n. 16, jan./jun. 2014. Disponível em: http://periodicos2.uesb.br/index.php/praxis/article/view/760. Acesso em: 12 fev. 2020.

SANTOS, José Jackson Reis dos. Especificidades dos saberes para a docência na educação de pessoas jovens e adultas. Revista Práxis Educacional, Vitória da Conquista, v. 6, n. 8, jan./jun. 2010. Disponível em: https://periodicos2.uesb.br/index.php/praxis/article/view/623. Acesso em: 13 fev. 2020. 
SANTOS, Mariana Fernandes dos; VALADARES, Flavio Biasutti; MACEDO, Yuri Miguel. (Des)encontros para um currículo afrocentrado no ensino de língua portuguesa na educação profissional técnica de nível médio integrada ao ensino médio. Revista Exitus, Santarém - PA, v. 9, n. 4, p. 204-231 2019. Disponível em:

http://www.ufopa.edu.br/portaldeperiodicos/index.php/revistaexitus/article/view/1010/526. Acesso em: 06 jul. 2020. https://doi.org/10.24065/2237-9460.2019v9n4ID1010.

SANTOS, Sônia Beatriz dos; DAMASCENO, Ilaina. Experiências de professoras/ intelectuais negras na universidade: entre o direito à diferença e a competência pedagógica. Revista Práxis Educacional, Vitória da Conquista - BA, v. 15, n. 32, p. 69-88, abr./jun. 2019. Disponível em: http://periodicos2.uesb.br/index.php/praxis/article/view/5044/3913. Acesso em: 07 jul. 2020. DOI: https://doi.org/10.22481/praxis.v15i32.5044.

SANTOS, Wolney Nascimento; DANTAS JUNIOR, Hamilcar Silveira; ZOBOLI, Fabio. Cinema, educação e africanidades: a memória no documentário Caixa d'água: qui-lombo é esse? Revista Educação \& Formação, Fortaleza - CE, v. 5, n. 15, p. 1-21, 2020. Disponível em: https://revistas.uece.br/index.php/redufor/article/view/2508/2654. Acesso em: 07 jul. 2020. DOI: https://doi.org/10.25053/redufor.v5i15set/dez.2508

SEPTIEN, Rosa Campoalegre. Una escuela tan negra como nosotras: desafíos ante el racismo y el patriarcado. Revista Práxis Educacional, Vitória da Conquista - BA, v. 15, n. 32, p. 17-32, 2019. Disponível em: http://periodicos2.uesb.br/index.php/praxis/article/view/5040/3910. Acesso em: 07 jul. 2020. DOI: https://doi.org/10.22481/praxis.v15i32.5040.

SILVA, Ana Célia da. Desconstruindo a discriminação do negro no livro didático. Salvador: EDUFBA, 2010.

SILVA, Arlene Santos; PINHEIRO, Bárbara Carine Soares. Químicxs negros e negras do século XX e o racismo institucional nas ciências. Revista Exitus, Santarém-PA, v. 9, n. 4, p. 121-146, 2019. Disponível em:

http://www.ufopa.edu.br/portaldeperiodicos/index.php/revistaexitus/article/view/1007/524. Acesso em: 06 jul. 2020. DOI: https://doi.org/10.24065/2237-9460.2019v9n4ID1007.

SILVA, Claudilene Maria da; SANTIAGO, Maria Eliete. Trabalho docente e construção de identidades: condições, possibilidades e limites do trabalho sobre relações étnico/raciais no espaço escolar. Revista Práxis Educacional, Vitória da Conquista - BA, v. 11, n. 18, p. 17-41, 2015. Disponível em: http://periodicos2.uesb.br/index.php/praxis/article/view/799/676. Acesso em: 06 jul. 2020.

SILVA, Nilson Robson Guedes. Gestão escolar democrática: uma contextualização do tema. Revista Práxis Educacional, Vitória da Conquista, v. 5, n. 6, jan./jun. 2009. Disponível em: http://periodicos2.uesb.br/index.php/praxis/article/view/590. Acesso em: 13 fev. 2020.

SOBRINHO, Roberto Sanches Mubarac. As culturas infantis indígenas e os saberes da escola: uma prática pedagógica dos (des)encontros. Revista Práxis Educacional, Vitória da Conquista, v. 6, n. 8, jan./jun. 2010. Disponível em: http://periodicos2.uesb.br/index.php/praxis/article/view/622. Acesso em: 14 fev. 2020. 
SOCORRO, Paulina Elena Villasmil; SANTOS, Arlete Ramos dos; NUNES, Claudio Pinto. Políticas públicas educativas en Latinoamérica: el contexto brasileño y el venezolano. Educação em Questão (online), v. 55, n. 45, p. 12-41, 2017. Disponível em:

https://periodicos.ufrn.br/educacaoemquestao/article/view/12743. Acesso em: 20 fev. 2020.

SOUSA, Jesus Maria. Repensar o currículo como emancipador. Revista Tempos e Espaços em Educação, São Cristóvão - SE, v. 9, n. 18, p. 111-120, 2016. Disponível em:

https://seer.ufs.br/index.php/revtee/article/view/4969. Acesso em: 07 jul. 2020. DOI: https://doi.org/10.20952/revtee.v9i18.4969.

SOUZA, Janyne Barbosa de; SANTOS José Jackson Reis dos; EUGÊNIO, Benedito Gonçalves. Avanços e desafios no processo de implementação da Lei 10639/03 na Rede Municipal de Ensino de Jequié-Ba: os discursos do campo recontextualizador oficial. Revista Práxis Educacional, Vitória da Conquista - BA, v. 11, n. 18, p. 177-197, jan./abr. 2015. Disponível em: http://periodicos2.uesb.br/index.php/praxis/article/view/806/683. Acesso em: 06 jul. 2020.

SOUZA, Lucas Colangeli de; DI GREGÓRIO, Maria de Fátima. Ensaio sobre a História e Cultura AfroBrasileira e Indígena Trabalhadas nas Salas de Aulas do Ensino Fundamental das Escolas Públicas no Nordeste do Brasil: Entre Desafios dos Livros Didáticos e Docência. Revista Tempos e Espaços em Educação, São Cristóvão - SE, v. 9, n. 19, p. 63-74, 2016. Disponível em: file:///C:/Users/Edmacy\%20Quirino/Downloads/5596-Texto\%20do\%20artigo-15735-1-1020160907\%20(1).pdf. Acesso em: 07 jul. 2020. DOI: 10.20952/revtee.2016vl9iss19pp 63-74.

TEIXEIRA, Eliara Cristina Nogueira; NUNES, Claudio Pinto. Os sentidos atribuídos ao piso salarial nacional como política pública de valorização docente. Revista Tempos e Espaços em Educação, Aracaju, v. 12, n. 29, p. 195-212, 2019. Disponível em:

https://seer.ufs.br/index.php/revtee/article/view/10688. Acesso em: 22 fev. 2020.

ULJENS, M. Non-Affirmative curriculum theory in a cosmopolitan era? Revista Tempos e Espaços em Educação, São Cristóvão - SE, v. 9, n. 18, p. 121-132, 2016. Disponível em: https://seer.ufs.br/index.php/revtee/article/view/4970. Acesso em: 21 mai. 2020. DOI: https://doi.org/10.20952/revtee.v9i18.4970.

VALENTIM, Silvani dos Santos; MOREIRA, Jane. Africanidades e tribalismo cultural: experiências de professores (as) da cidade africana de Obuasi, Ghana. Revista Práxis Educacional, Vitória da Conquista - BA, v. 16, n. 39, p. 115-137, 2020. Disponível em:

http://periodicos2.uesb.br/index.php/praxis/article/view/6362/4695. Acesso em: 07 jul. 2020. DOI: https://doi.org/10.22481/praxisedu.v16i39.6362

ZOTTI, Solange Aparecida. O currículo no Brasil Colônia: proposta de uma educação para a elite. Revista Práxis Educacional, Vitória da Conquista - BA, n. 2. p. 115-140, 2006. Disponível em http://periodicos2.uesb.br/index.php/praxis/article/view/516/413. Acesso em: 06 jul. 2020. 


\section{SOBRE AS AUTORAS}

\section{Arlete Ramos dos Santos}

Pós-Doutorado em Educação e Movimentos Sociais pela UNESP, Doutora e Mestre em Educação (FAE/UFMG). Professora Titular da Universidade Estadual do Sudoeste da Bahia; Professora do Programa de Pós-Graduação, Mestrado em Educação da UESB (PPGEd/Uesb); Profa. do PPGE/UESC; Coordenadora do Grupo de Estudos e Pesquisas em Movimentos Sociais, Diversidade e Educação do Campo e Cidade - Gepemdecc/CNPq.

E-mail: arlerp@hotmail.com

Orcid: https://orcid.org/0000-0003-0217-3805

\section{Edmacy Quirina de Souza}

Doutora em Educação pela Universidade Federal de São Carlos (UFSCar); Professora Adjunta da Universidade Estadual do Sudoeste da Bahia (UESB); Faz parte do Programa de Pós-Graduação em Educação (PPGEd/UESB); Vice líder do Grupo de Pesquisa Infância, Educação e Contemporaneidade (GPIEC/CNPq); Pesquisadora do Grupo de Estudos e Pesquisas em Movimentos Sociais, Diversidade e Educação do Campo e Cidade - GEPEMDECC/CNPq.

E-mail: macy.souza@hotmail.com

ORCID https://orcid.org/0000-0002-6712-1021

\section{Letícia Freitas Azevedo}

Mestrado em Educação Científica e Formação de Professores pelo Programa de Pós-Graduação Educação Científica e Formação de Professores (PPG-ECFP) da Universidade Estadual do Sudoeste da Bahia (UESB). Professora da UESB, campus de Itapetinga. Pesquisadora do Grupo de Estudos e Pesquisas em Movimentos Sociais, Diversidade e Educação do Campo e Cidade GEPEMDECC/CNPq.

E-mail: leticiaazevedo91@hotmail.com

ORCID: http://orcid.org/0000-0003-0325-7680

Recebido em: 15 de maio de 2020

Aprovado em: 02 de julho de 2020

Publicado em: 07 de julho de 2020 